Article

\title{
Evaluation of the Visitor Understanding of Coastal Geotourism and Geoheritage Potential Based on Sustainable Regional Development in Western Black Sea Region, Turkey
}

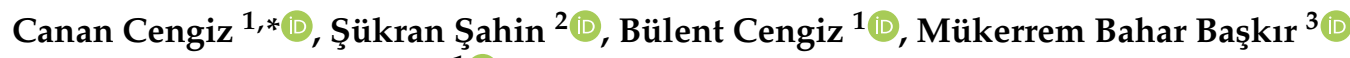 \\ and Pelin Keçecioğlu Dağlı ${ }^{1}$ (I) \\ 1 Department of Landscape Architecture, Faculty of Engineering, Architecture and Design, Bartın University, \\ 74100 Bartın, Turkey; bcengiz@bartin.edu.tr (B.C.); pkececioglu@bartin.edu.tr (P.K.D.) \\ 2 Department of Landscape Architecture, Faculty of Agriculture, Ankara University, 06110 Ankara, Turkey; \\ sukran.sahin@ankara.edu.tr \\ 3 Department of Statistics, Faculty of Science, Bartın University, 74100 Bartın, Turkey; mbaskir@bartin.edu.tr \\ * Correspondence: canancengiz@bartin.edu.tr; Tel.: +90-505-573-27-75
}

check for

updates

Citation: Cengiz, C.; Şahin, Ş.;

Cengiz, B.; Başkır, M.B.;

Keçecioğlu Dağlı, P. Evaluation of

the Visitor Understanding of Coastal

Geotourism and Geoheritage

Potential Based on Sustainable

Regional Development in Western

Black Sea Region, Turkey.

Sustainability 2021, 13, 11812.

https: / / doi.org/10.3390/

su132111812

Academic Editors: Mario Bentivenga,

Fabrizio Terenzio Gizzi,

Giuseppe Palladino and

Eva Pescatore

Received: 4 September 2021

Accepted: 22 October 2021

Published: 26 October 2021

Publisher's Note: MDPI stays neutral with regard to jurisdictional claims in published maps and institutional affiliations.

Copyright: (c) 2021 by the authors. Licensee MDPI, Basel, Switzerland. This article is an open access article distributed under the terms and conditions of the Creative Commons Attribution (CC BY) license (https:// creativecommons.org/licenses/by/ $4.0 /)$.
Abstract: The Black Sea coasts of Turkey have important examples of geological heritage with coastal cliffs in terms of geological formations and features. The Güzelcehisar Basalt Columns (GBCs) formation and its coast have been chosen as a research area in this article in terms of its basalt columns, rare coastal geological diversity and coastal geotourism potential. This paper presents the results of a visitor survey undertaken at the GBCs formation and its coast, located in the rural coastal part of Bartın province in the Western Black Sea Region of Turkey. This survey was conducted in 2020 to assess the tourism shoulder season visitors to the Güzelcehisar village. With the survey, its aim was to determine the awareness of the visitors on geoconservation and geodiversity and to evaluate the understanding of geological heritage and geotourism. In addition, it was desired to set visitor expectations to improve the geotourism experience. It was found that visitors had a high level of understanding and awareness of the terms "geodiversity", "geoheritage", "geotourism" and "geoconservation". However, this survey also shows that there is less emphasis on the need to protect the geodiversity in Güzelcehisar. Guided walking is preferred in order to improve visitor understanding and improve experiences. These survey findings contain guiding explanations for studies that could provide a wider interpretation of the perceptions, experiences and expectations of visitors regarding the sustainable development of areas with similar coastal geotourism potential in Turkey.

Keywords: coastal geotourism; heritage coast; geodiversity; geoheritage; geosite; Güzelcehisar; Bartın; statistical analysis; survey

\section{Introduction}

Special geological formations have long attracted visitors from around the world. One of the newest concepts among today's tourism types is geotourism. In the last few decades, both the level of interest in geotourism [1] and the scientific interest in geoheritage have increased rapidly [2]. Hose [3] defined geotourism as a "provision of interpretive and service facilities to enable tourists to acquire knowledge and understanding of the geology and geomorphology of a site (including its contribution to the development of the Earth sciences) beyond the level of mere aesthetic appreciation" [1]. Newsome and Dowling [4] later defined geotourism as "tourism which focuses on an area's geology and landscape as the basis of fostering sustainable tourism development".

In the concept of "world heritage", which has become increasingly important in recent years, its evaluation, management and protection, besides biodiversity, geological diversity (geodiversity) and geoconservation issues are also highlighted [5]. Geological diversity is 
an important issue for future geological heritage management strategies [6]. Geodiversity and geoconservation issues include the interpretation of geological information, raising awareness and understanding of areas of geological or geomorphological significance, and tourism associated with geosites [7].

Geosites are defined as a place or area that displays interesting geological features that allow an understanding of rocks, minerals, fossils and landscape [6]. Geological heritage areas, which are part of the global heritage, are defined as areas that include special and rare places and objects that play an important role in understanding the history of the Earth $[6,8,9]$. A geosite is generally understood as a geo(morpho)logical heritage or geoheritage that represents one or more unique features related to geological and/or geomorphological processes [10]. According to Brilha [11], geoheritage is a general but descriptive term used for geological features or areas of significant scientific, educational, cultural or aesthetic value [12].

The clear definition of the term geosite was determined by Reynard [13] as follows: "Geosites are parts of the geosphere that are of particular importance for the understanding of world history. More specifically, geosites are scientific (e.g., sedimentological stratotype, being a relict morin representative be of a glacial extension), cultural/historical (e.g., religious or mystical value), aesthetic (e.g., mountain or coastal landscapes), and/or social/economic (e.g., as tourist attractions aesthetic landscapes) are values" [10]. According to Geremia [14], geosite studies serve to increase the general awareness of administrators Bentivenga [9] and society at a local and national level about the geological heritage.

Geoconservation covers the recognition, protection, evaluation and management of high geodiversity areas and landscapes for tourism, science and education purposes [2,7,15-17].

In this context, geotourism is defined as the type of tourism that is formed to increase the awareness and understanding of geological information in arrangements that include geo area (geologically or geomorphologically interesting places) features and explanatory materials [7]. Geotourism is based on sustainability-based principles [10,18]. Geotourism is a form of tourism that allows the geological features of the visited regions to be explored together with other natural and cultural resource values [9]. A successful geotourism application makes the visit meaningful and memorable, depending on the quality of the visitor experience $[19,20]$. There has been an increasing focus on geotourism as a means of realizing sustainable development through enhancing financial power [2,18], on the one hand, and environment conservation, on the other [21,22]. For a sustainable regional development and geotourism, the detection, the utilization and protection of geological heritage areas is of great significance [23]. Geotourism is becoming an important source of income in many rural areas [8,24,25]. In conclusion, geotourism is a conservation tool that provides a sustainable source of economic benefits for the region, as stated by Garofano [18,26]. In addition, investing in geoconservation efforts and the development of geological heritage for sustainable tourism can create new business opportunities associated with geotourism. When associated with other tourist attractions, the presence of geosites significantly increases the number of visitors to an area [9].

The value of an area of interest to visitors (geosite, geomorphosite or geological heritage site-primary area of interest in geotourism) can be expressed through specific assessment methods. However, geosite assessment methods in the literature have primarily focused on various aspects of geotourism (e.g., location, scientific value, representativeness, etc.) $[10,18]$. However, in such places, the development of geotourism will not be possible without the interest of the visitors [10]. It is important to focus on visitor preferences and motivations in order to obtain data on visitor understanding, expectations and visitor satisfaction [20]. Relevant visitor data information (geo), included in the assessment, is important for tourism development and future geosite development and management activities [10].

Community involvement in the conservation and evaluation procedures of geological heritage is emphasized by all, because community perceptions have the potential to help 
protect and conserve local geological sites and increase public awareness of environmental issues [18].

According to the results of Ólafsdóttir and Tverijonaite [1], it is stated that the participation of geotourism stakeholder groups (such as tourists and local communities) is not adequately included in the studies. At the same time, few scientific studies on geotourism on the basis of sustainable development $[2,5,7,18,20,22,27-29]$ appear in the literature. Focusing on visitor preferences and/or motivations in the evaluation of geosites has significantly impacted the success and sustainability of various forms of naturally based tourism recently represented primarily by geotourism and ecotourism [10].

The Black Sea coasts of Turkey have important examples of geological heritage with coastal cliffs in terms of geological formations and features. The Güzelcehisar Basalt Columns (GBCs) formation and its coast have been chosen as a research area in this article in terms of its basalt columns, rare coastal geological diversity and coastal geotourism potential. There are few scientific studies on geotourism on the basis of sustainable development in Turkey. This study has scientific importance for the study of rural coastal landscapes, which show a valuable geodiversity in terms of coastal geomorphology. For the development of coastal geotourism, the Güzelcehisar rural coastal region, which has unique landscape features, is taken as a reference. The study presents considerations for promoting the research area to enhance and preserve its geoheritage value through coastal geotourism activities and improving visitor experience through a participatory approach.

The main purpose of the research is to determine the understanding of visitors in terms of the geoheritage and coastal geotourism potential of the Güzelcehisar Basalt Columns (GBCs). With the survey, the aim is to determine the awareness of the visitors on geoconservation and geodiversity and to evaluate the understanding of geological heritage and geotourism. In addition, it was desired to set visitor expectations to improve the geotourism experience.

\subsection{Geoheritage and Geotourism in Turkey}

Turkey has important tourism centers and potential areas with its underground and surface natural and cultural diversity. Especially since the last twenty years, studies have been carried out to determine the geological heritage and to protect the geological formations [30].

In our country, the Geological Heritage Preservation Society was established in 2000 (JEMIRKO), although there are numerous geological formations in Turkey, only 28 areas have been identified and qualified as Geological Heritage Sites [30]. On the other hand, Turkey's first and only registered geopark accepted by UNESCO is the Kula UNESCO Global Geopark since 2013. Kula, which is the 58th Geopark of Europe and the 99th Geopark of the World, is included in the UNESCO Global Geoparks Network. On the other hand, the Balikesir's Ida-Madra Geopark application is under evaluation at UNESCO. Letters of intent for the Nevşehir Cappadocia Geopark and Zonguldak Coal Geopark projects have been submitted to UNESCO.

Turkey has areas with high geotourism potential in terms of the results of important events in geological history and the concrete forms formed in their processes; for example, canyons (Tokatlı Canyon, Sansarak Canyon), mountains (Küre Mountains National Park, Mount Erciyes, Mount Ağrı), lakes (Aygır maar and its lake (Bitlis), Lake Van, Lake Eğridir, Salt Lake, Lake Akşehir), basaltic columns (Güzelcehisar, Kızılcahamam), Lava channel on tuffs (Afyon) and waterfalls (Tortum). In addition, there are other landforms known with geotourism potential in Turkey. These include a wide variety of geological formations such as the Fairy Chimneys (Cappadocia), potholes (Konya) and caves (Damlataş cave, Ballica cave).

Scientific studies within the scope of geological heritage and geoconservation in Turkey: Yeşil [30] explained the alternative tourism phenomenon within the scope of geological heritage sites in the case of the Ballica Cave; Keskin Citiroglu [23]—the subject of benefiting from geological diversity for sustainable regional development in Zonguldak; 
Çelik Ateş and Ateş [31] — the synergy of geotourism and rural tourism for sustainable development in Maçka Valley Tunceli; Demir and Aytaç [32]—Turkey's first and only UNESCO-registered global geopark Kula UNESCO Global Geopark; Köroğlu and Kandemir [27]—sensitive geosites for Çal Camili Natural Park (Düzköy—Trabzon) region; Özgeriş and Karahan [33] evaluated the evaluation of geopark resource values for sustainable tourism in the case of Cittaslow city Uzundere. Ertekin [34] attempts to assess the geosites of the Nemrut volcano (Bitlis) and proposes using these areas as a geopark and geoheritage site. The first applied geoconservation and geotourism activity in Turkey is the Kızılcahamam, Çamlıdere Geopark and Geotourism Project, which was carried out in cooperation with the relevant municipalities and district governorships between 2009 and 2012 under the direction of Ankara University [35-37]. Landscape design was determined for five geosite areas within the scope of the project, within the scope of The Scientific and Technological Research Council of Turkey (TÜBITAK) project $[35,36]$, which was produced simultaneously, and two trainings were held for local stakeholders as there were hardly any visitors to the area yet. Project hypotheses were tested with questionnaires administered to the participants.

\subsection{Research Background and Aims}

To date, many international studies have been carried out in the fields of geotourism and geoheritage. The trend of international studies is shifting from "defining and analyzing geo-resources" to focusing on "conservation and management of geo-resources" [22]. In this context, it can be stated that Turkey is at the stage of defining and analyzing its geoheritage potential. On the other hand, Turkey still has only one registered geopark (Kula-Manisa) accepted by UNESCO. For this reason, identifying and defining areas with high geo-heritage potential in Turkey and revealing the awareness and understanding of visitors are important in terms of geoheritage and coastal geotourism on the basis of sustainable development.

This article is unique as it is the first study conducted using a participatory approach on the coastal geotourism of the Güzelcehisar Basalt Columns (GBCs) and coast, which have an international importance with their geological features. In addition to determining the visitor's understanding of the geoheritage and coastal geotourism potential of the research area with the study, the survey analysis/results obtained contain guiding results regarding the conservation and management of the geoheritage in Güzelcehisar in the future.

Previous scientific studies on the study area are as follows: ecological plan proposal for the Güzelcehisar coastal settlement [38], Güzelcehisar coastal landscape heritage project [39], Landscape Application Project for Tourism and Recreation Purposes for The City of Bartın Güzelcehisar Lava Columns and Coast [40] and visual landscape assessment in coastal areas in the example of Güzelcehisar village for the sustainable development of rural landscapes [41].

\section{Conceptual Framework and Research Questions}

The World Tourism Organization (UNWTO) [42] has stated that "tourism is one of the driving forces of global economic growth and currently provides for 1 in 11 jobs worldwide".

Tourism, and especially rural tourism, which has become an engine of local development, increases the well-being of the local population [43,44]. The tourism types that will be developed in rural areas should be considered a factor in local development and should be encouraged as a vital factor in increasing people's quality of life. Such tourism should also contribute to the invigoration of the economy to help local people to have a higher standard of living [43]. Many countries try to be a smart and sustainable tourist destination which makes tourist's interaction with the environment easy and which improves the local people's quality of life [45]. The cooperation between tourists and local people should be a frame of reference for the advertising of these places which are called smart tourist destinations $[46,47]$. However, these destinations should be considered as smart touristic regions instead of individual places $[47,48]$. Rural areas can have productive activities 
based on tourism only if they are sustainable in terms of both the environment and local people [47].

These touristic areas should have natural resources, on which a strategically planned touristic activities can be based. These natural resources can be any natural setting that creates a motivation for a touristic trip [43].

Sustainable Development Goals, defined by the UN in 2017, especially within the objective of "Decent Work and Economic Growth", encourage sustainable tourism which focuses on employment, culture and local development [49].

Rural tourism development must meet the needs of the host community and achieve the following requirements: fostering social inclusion and providing youth employment, being an alternative for diversifying and restructuring rural areas, promoting environmental conservation and improving the understanding of the cultural values of different locations and generating wealth for local residents [43].

However, in order for such tourism to be a factor for local development, it is very important to preserve the quality of the environment of the natural resources, which will make this activity possible [50]. Tourism is a critical industry due to its vast potential to develop and improve regional competitiveness [51]. Sustainability should be a strategic goal for any destination [50]. The sustainability of touristic destinations is a differentiating factor that increases the competitive power [43,52].

The main purpose of the research is to determine the understanding of visitors in terms of the geoheritage and coastal geotourism potential of GBCs. This article poses four main research questions for which it attempts to provide answers:

(i) What are the perceptions and understandings of the visitors regarding geodiversity, geoconservation and geoheritage?

(ii) What should be conducted to improve the visitor experience during a field visit?

(iii) What is the relationship between geodiversity and other touristic and recreational activities in terms of visitor experience?

(iv) How will diversification of tourism in the study area contribute to sustainable local development?

\section{Study Area}

Güzelcehisar is a coastal settlement area of Bartın Province, located in the Western Black Sea Region of Turkey. Located in the west of Bartın city center, Güzelcehisar is located approximately $17 \mathrm{~km}$ from the city center (Figure 1).

Güzelcehisar is a settlement area where the influences of Amasra and the Genoese who settled in Amasra are seen in its historical past. Amasra, which remained within the borders of the Byzantine Empire for many years, passed to the Genoese in 1263. The Genoese built a castle in the village, whose livelihood was maritime, and a fortress on the dominant rocks overlooking the bay [53]. Güzelcehisar Castle is a defense structure against attacks from the sea. The castle is similar to Amasra Castle in terms of its architectural features.

Bartin Province is under the influence of one of the branches of the North Anatolian Fault line, which is one of the main fault zones of Turkey, extending towards western Anatolia. According to the Turkey Earthquake Map prepared by the Earthquake Research Center, Güzelcehisar is located in the 1st degree earthquake zone [54]. In the 1/100.000 scaled Geological Map of Turkey, it consists of andesite, spilite and porforite materials as a geological structure. The geology of the study area consists of Quaternary aged marine beach alluvium, the Middle-Upper Devonian-Lower Carboniferous Yılanlı Formation and Upper Cretaceous Yemişliçay Formation. Within the boundaries of the study area, andesite blocks and limestones were encountered.

The Black Sea climate prevails in Güzelcehisar, with hot summers and cool winters. The proximity to the sea and the fact that the mountain ranges that are not high are parallel to the coast generally cause a decrease in temperature differences on the coastline, an increase in humidity and the effect of air masses coming from the Balkans [54]. However, 
unlike the Black Sea climate, it exhibits a climate similar to the Mediterranean climate with its microclimatic feature. 


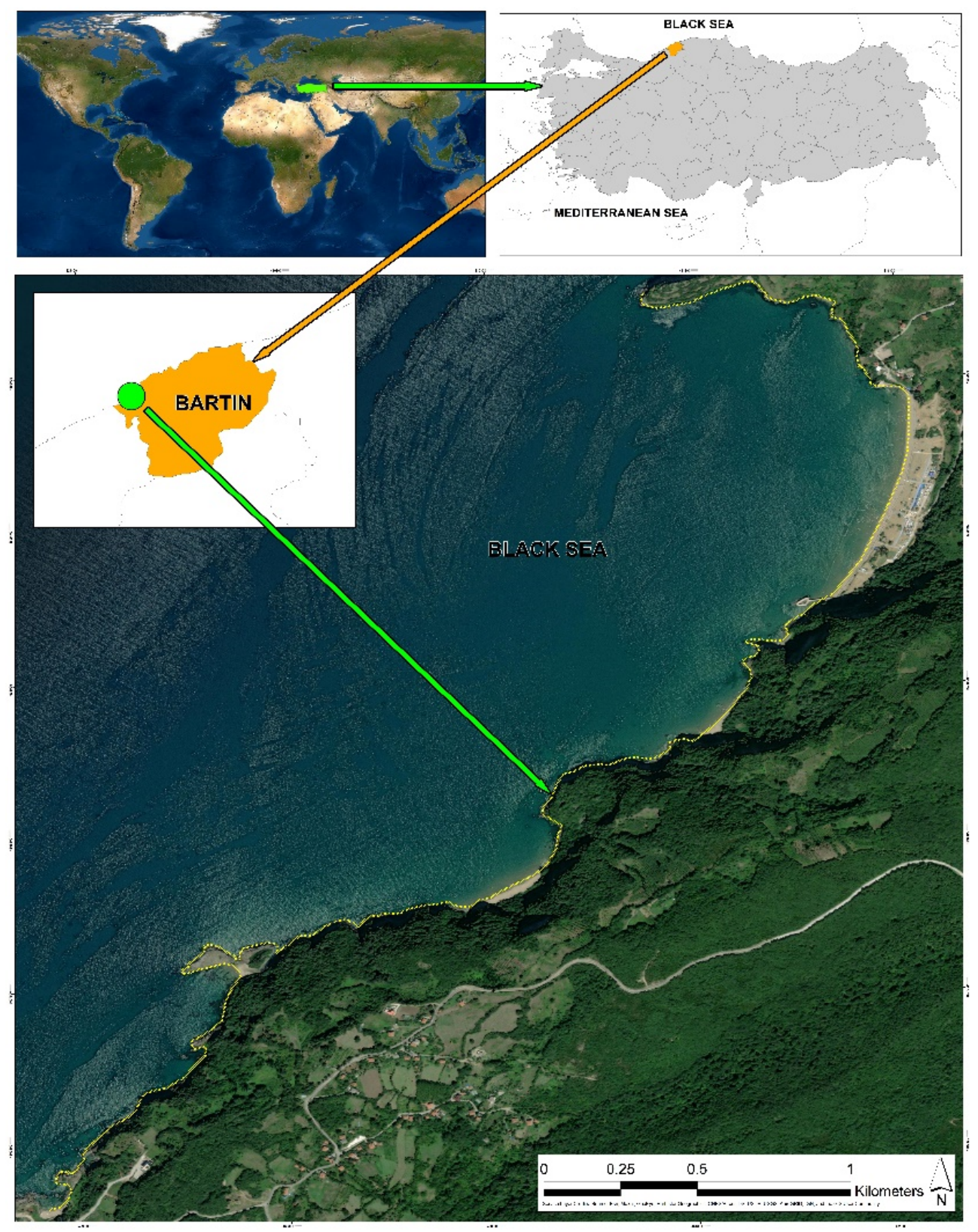

Figure 1. The Google Earth image of the location of the study area.

The geology of the study area consists of Quaternary aged marine beach alluvium, the Middle-Upper Devonian-Lower Carboniferous Yilanlı Formation and Upper Cretaceous Yemişliçay Formation (Figure 2). Andesite blocks and limestones were encountered within the boundaries of the study area [40], from the Black Sea to around Güzelcehisar or the northwest of Kapaklı. We included them tentatively in the Upper Devonian-Tournesian period together without having separated them [55].

At the end of the Paleozoic era, folds in the form of normal folds, inverted folds, flexures and fractures terminated the Variscan orogeny and, after that, a general emersion of the region took place. This emersion lasted until the infracretaceous transgression (or a little older, in the southeast), which first deposited a base conglomerate. This transgression could not cover the whole region; among the points spared by this marine movement, we could cite Yaylacık Tepe, Gâvurpınarı, Gürgenpınar and the region of Güzelcehisar which remained emerged until the Turonian period. (Transgressive Turonian directly on the different stages of the Paleozoic period [55].) 


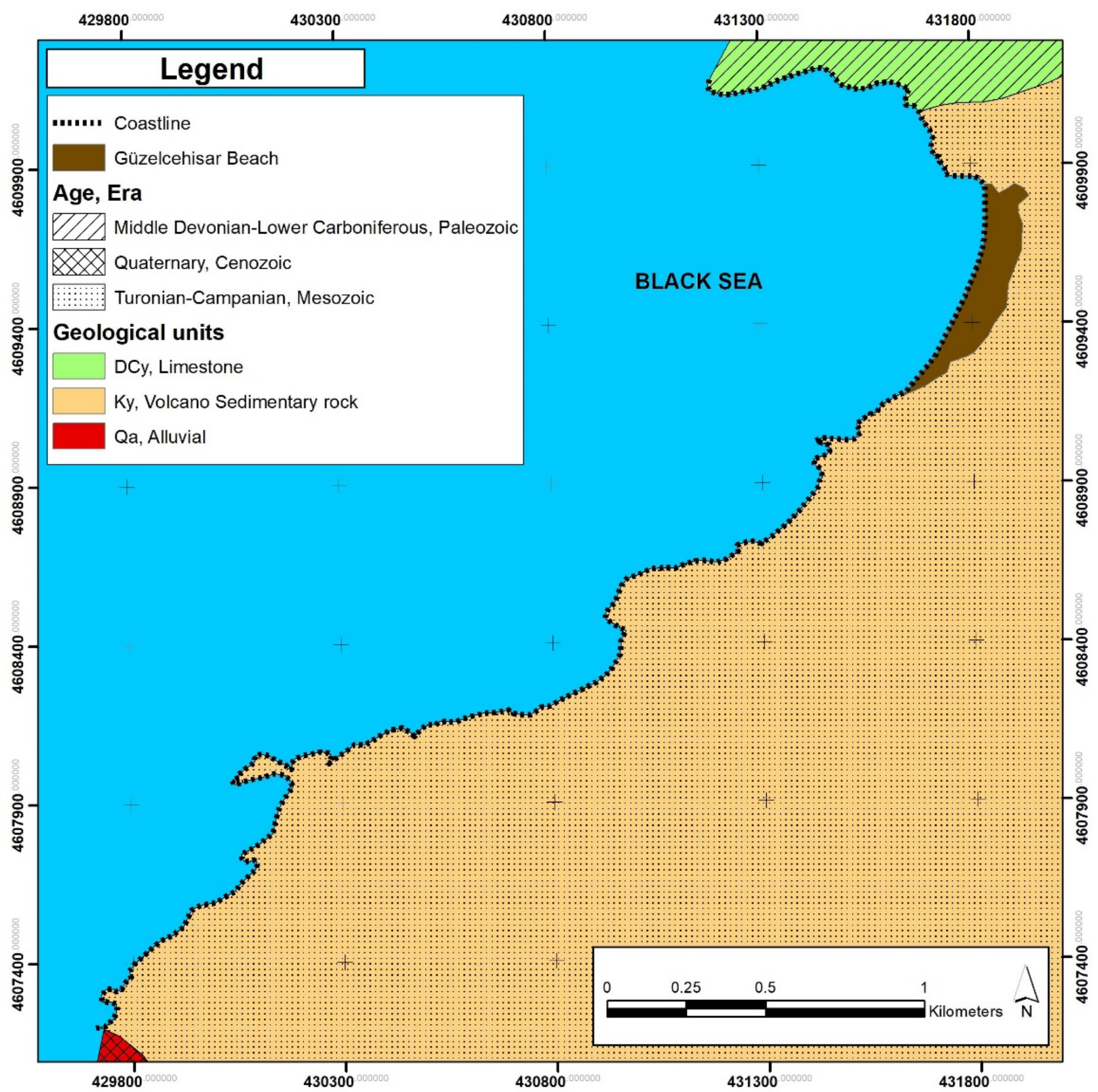

Figure 2. Geology of the study area [55].

Due to its volcanic structure, Güzelcehisar has geomorphological formations called "Basalt Columns" in the coastal area. Diameters of the Basalt Columns are 50-100 cm and their height is over $30 \mathrm{~m}$. They are located along the coast of about $5 \mathrm{~km}$ long (Figure 3). The Northern Ireland, Scotland and California Lava Columns, especially, are among the international tourism centers [40]. In Turkey, GBCs are one of the rarest developed natural formations of the world and have national and international tourism potential.

Magma rocks formed as a result of volcanic activities observed in Turkey, starting from the vicinity of İgneada in the west, towards the east, from Şile, Marmara Ereğlisi, Zonguldak, Bartın, İnebolu and the entire Black Sea mountain belt. However, the feature that distinguishes Güzelcehisar from its peers and places it at the forefront is that its basalt columns extend all the way to Mugada Bay, which is a natural wonder [40].

Lava flowing from a volcano shrinks as a natural result of cooling and solidification as it cools and crystallizes into rock. This shrinkage caused by cooling creates stress in the rock and as a result cracks develop. As the lava cools, the contraction continues and, thus, 
the cracks that form gradually become larger. Although these fractures develop in a wide variety of ways, they cause the rock to acquire a hexagonal, pentagonal or quadrangular structure where they occur in an extremely regular and systematic manner. Triangle and heptagonal species can develop, albeit rarely. This regular geometric structure is called a "column" or column structure. Basalt columns in Güzelcehisar caused the formation of coastal cliffs. The topographic structure of the area consists of rough slopes rising from the sea level in accordance with the land structure unique to the Black Sea (Figure 4).

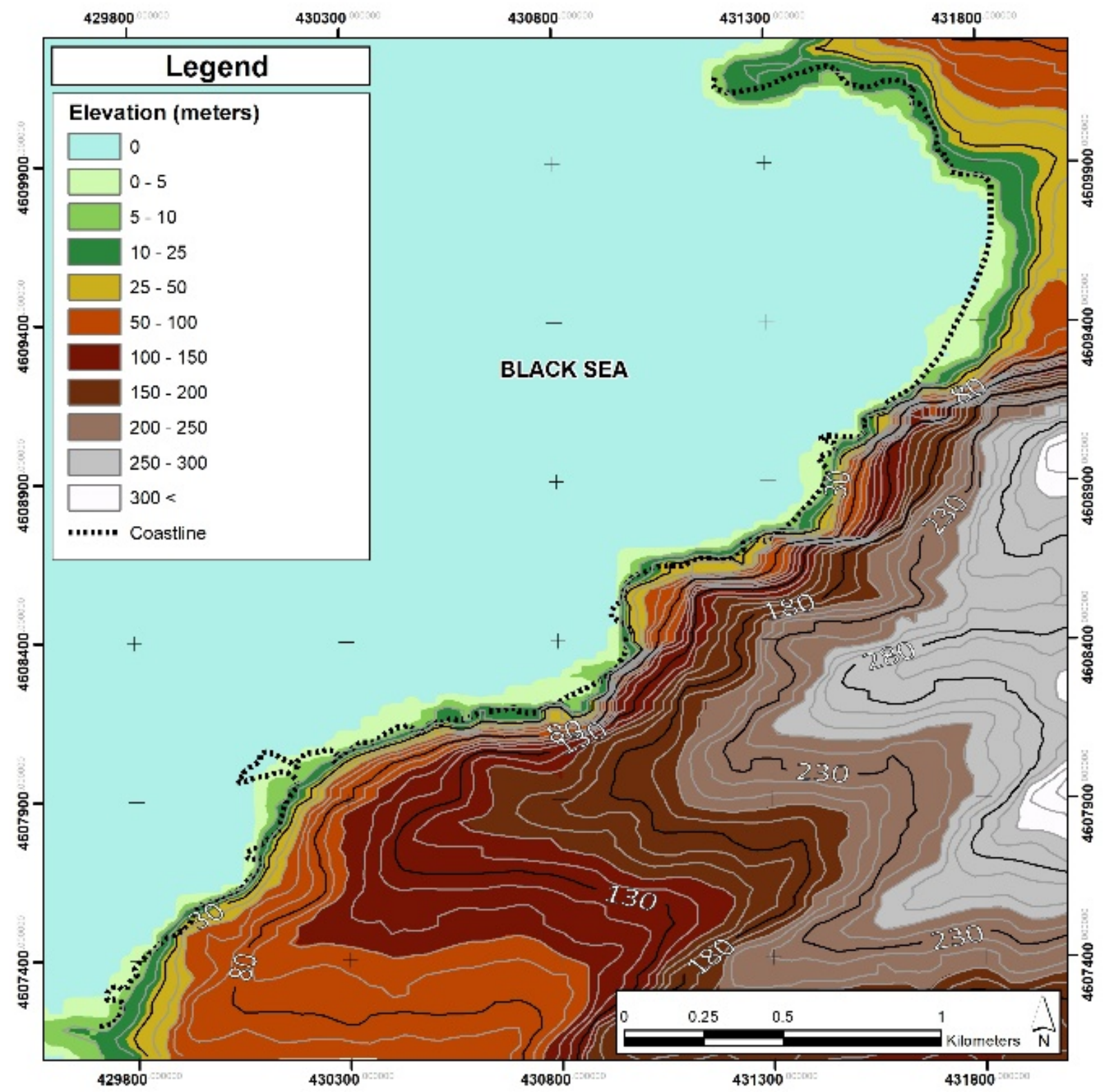

Figure 3. Topography of the study area [40].

Vegetation in the Black Sea Region, plant groups and species longing to both the Black Sea and the Euro-Siberian plant geography could be seen. Located on the Davis A4 square, Güzelcehisar is one of the most interesting and richest forest areas in Turkey in terms of forest areas, plant and tree species richness and wild animals. From woody plants (Stem oak (Quercus robur), Sapless oak (Quercus patreae), Eastern beech (Fagus orientalis), Western hornbeam (Carpinus betulus), Anatolian chestnut (Castanea sativa), Pine (Pinus pinea), Common hazel (Coryllus colurna), Goat Willow (Salix caprea), Cluster willow (Salix babylonica) and Wild Cherry (Cerasus avium) plantations) being common, to ground 
cover plants (Blackberry (Rubus sp.), Rosehip (Rosa canina), Muletoe (Spartium junceum), Daphne (Daphne sp.), Laurel (Laurus nobilis), Forest creeper (Hedera sp.), Rhododendron (Rhododendron sp.), holly (Ilex aquifolium), Fern (Pteridium aquilinum), Cabbage (Tussilago sp.), Nettle (Urtica sp.) and plantations) [38].
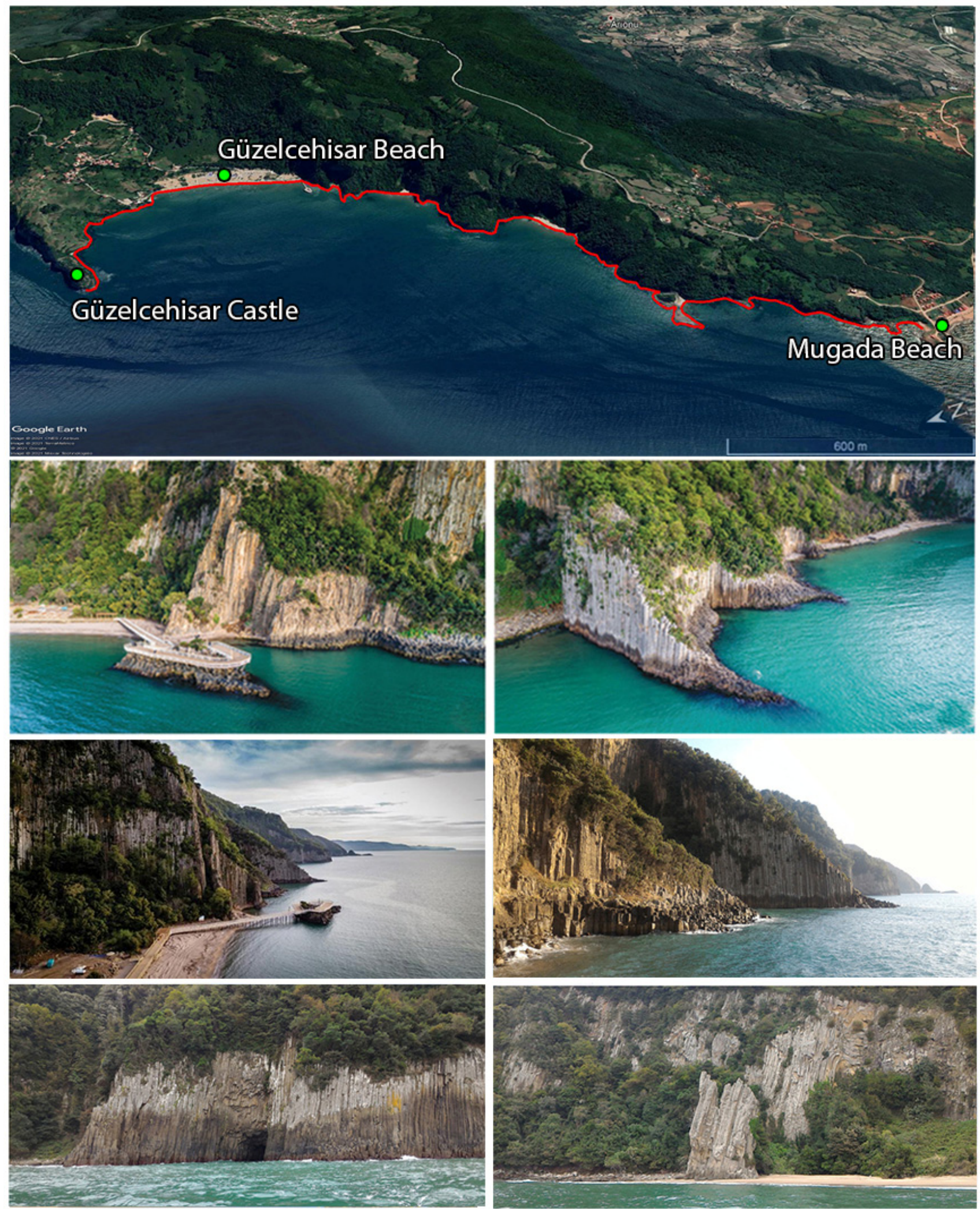

Figure 4. Güzelcehisar coast and basalt columns [40]. 
Looking at the current land use data, forest areas, settled areas, agricultural areas, rocky areas and sandy beaches were the main land use types. In the 1st Degree Archaeological Site, there were dense forests and rocks, but it is surrounded by agricultural areas. Access to the First Degree Archaeological Site was provided by an unstable path through the agricultural areas [54].

Various studies have been carried out to protect the GBCs and their coast in the national status. These are, respectively, Güzelcehisar beach, which was declared a first degree natural protected area, and Güzelcehisar castle, which was declared a first degree archaeological site. In 2017, the zoning plan for the protection of the Güzelcehisar coast came into effect. In line with this plan, the "Landscape Application Project for Tourism and Recreation Purposes for The City of Bartın Güzelcehisar Lava Columns and Coast" supported by the Western Black Sea Development Agency (BAKKA) was completed in 2018. The project included a coastal arrangement and pier applications for the visibility and accessibility of the GBCs. The Basalt columns were declared a Nature Park by the General Directorate of Nature Conservation and National Parks in 2017. Various projects for the development of ecotourism have been implemented in Güzelcehisar village with the projects supported by BAKKA since 2020. It is on the Geological Heritage Site Inventory List in Turkey (Figure 5).
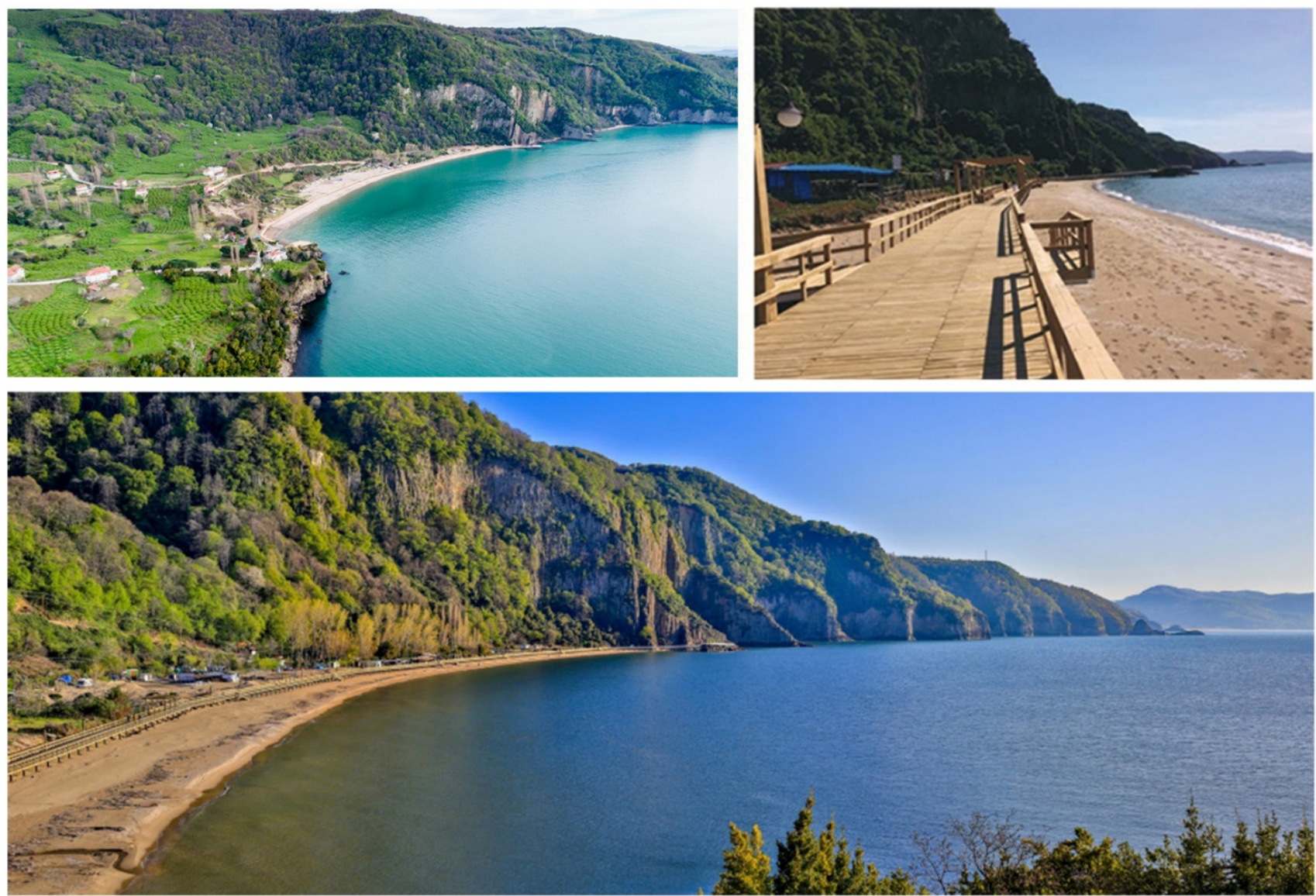

Figure 5. Güzelcehisar coast and boardwalk [40].

In order to promote the GBCs and their coast in the international status, it is necessary to pay attention to the necessary studies for inclusion in the UNESCO Global Geopark network and the world heritage list. 


\section{Methods}

Data collection: Data were collected by survey measurement and evaluation method. A survey was conducted to determine the visitor profile and understanding of geoheritage and its coastal geotourism potential.

SWOT analysis: SWOT analysis was carried out in line with the data obtained from the literature surveys [38-41] and field studies and observations determined on site. In addition, the studies of Özgeriş and Karahan [33] and Chauhan [56] were taken as references.

Survey: A face-to-face survey was conducted with visitors in order to determine what needed to be conducted to improve the visitor experience, to determine awareness of geoconservation and geodiversity and to evaluate visitors' understanding of geological heritage and geotourism. In particular, the aims of the survey were:

- Determining the socio-demographic structure of the visitors;

- Determining the perception and understanding of the visitors regarding the concepts of "Geological diversity", "Geoheritage" and "Geoconservation";

- Identifying awareness of the natural and cultural characteristics of Güzelcehisar;

- Determining the opinions and ideas about the geological features of the GBCs;

- Determining the criteria affecting the visit of the site and measuring the understanding of the adequacy of the information about the geological features of the site;

- Identifying what needs to be conducted to improve visitor experiences during site visits;

- Revealing the relationship of geodiversity with other touristic and recreational activities based on visitor experience;

- Integrating the understanding of geological heritage into tourism (geoheritage understanding engagement with tourism);

- After the visitor experience, it was aimed to obtain on-site interpretations and ideas about the memorable image of the area and the protection of geological features.

In order to determine the profile of the people who visited the Güzelcehisar area, a comprehensive questionnaire was created with four titles. The studies of Crawford and Black [7], Tavares [18], Štrba [10] and Santos [2] were used to create the questionnaire. This comprehensive survey was examined by 15 experts according to its purpose, content and question structure and reached its final form. The survey was applied face-to-face with 161 randomly selected people who visited the area recently. The survey was applied between 1 September and 1 December 2020, between 11.00 and 17.00 on the weekend, during which natural and cultural activities were attended together during field visits, apart from the busy summer tourism season. Since the questionnaire was administered during the pandemic, it was answered by a limited number of visitors. The pandemic had an impact on the sample size. As the survey was conducted outside the peak summer tourist season, it is not intended to represent the full profile of visitors to Güzelcehisar. However, it provides descriptive information about the visitor's understanding, knowledge and experience about geodiversity, geoheritage, geoconservation and coastal geotourism in the research area.

Survey titles and question distributions were as follows:

Demographic information: There were eight questions covering the demographic characteristics of the participants visiting the site and their familiarity with the basic concepts specific to the geological structure.

Area characteristics: There were eight questions created to determine the profile of the participants regarding the area characteristics and the natural and cultural aspects that were effective in the visit. Each question included a different number of answers-choices related to the area characteristics and the natural and cultural aspects.

Criteria affecting the area visit: Along with the visit schedule, there were 19 questions that evaluated the area's suitability for visitation. Five of these questions were 5-pointLikert-type questions ( $1 \rightarrow$ strongly disagree, $2 \rightarrow$ disagree, $3 \rightarrow$ neutral, $4 \rightarrow$ agree, $5 \rightarrow$ strongly disagree) related to GBCs' visit experience. Each of the remaining questions 
included a different number of answers-choices. One of them was related to measuring the impact of the COVID-19 pandemic on area visits.

Factors perceived during the area visit: There were five questions containing general and geological participant evaluations of the area visit. Each question included a different number of answers-choices regarding area-based impressions.

Data evaluation: Frequency distributions, chi-square test and reliability analysis were performed for the survey responses. Excel 2016 program was used to visualize the data. The frequency distribution was used to find the frequency (number of individuals falling into the relevant category) and percentage (frequency expressed as a percentage) of each variable. Reliability analysis was performed with SPSS Statistics software for Windows, V.26.0 (SPSS, Chicago, IL, USA). Whether there was a statistically significant relationship between two categorical variables was examined with the chi-square independence test. Chi-square independence tests and heatmap graphics were created with the codes written in MATLAB R2019b program. A " $p$ " value less than 0.05 was considered significant for statistical tests.

\section{Results}

\subsection{SWOT}

A SWOT analysis was carried out to determine the current status of the study area. The SWOT analysis was carried out in line with the literature surveys, field studies and observations determined on site. Moreover, the studies of Özgeriş and Karahan [33] and Chauhan [56] were used. The SWOT analysis of Guzelcehisar is given in Table 1. The application of the SWOT analysis was to determine GBCs' strengths, weaknesses, opportunities and threats in terms of accessibility/visibility, tourism and recreational usage, sustainability and rural development (Table 1).

\subsection{Survey Results}

A comprehensive questionnaire was answered by 161 randomly selected people who visited the area. The COVID-19 pandemic conditions and limitations effected the determination of the sample size and study design. The sample size was 161, which involved a sampling error of $\pm 7.72 \%$ with a confidence interval of $95 \%$ and $p=q=0.5$. The survey was applied to the selected participants, who visited the area between 1 September and 1 December 2020, between 11.00 and 17.00 on the weekends. In total, 42 homogenous time periods between 11.00 and 17.00 on the weekends were randomly selected. Four participants per each time period answered the questionnaire. Seven response forms from 168 participants were cancelled due to the incorrect information of the participants. In total, $52.8 \%$ of the respondents were female ( $n=85$, mean age: 39.18 , std deviation: 14.71$)$, $47.2 \%$ were male ( $n=76$, mean age: 42.74 , std-dev: 15.95$)$. In total, $21.1 \%$ of the participants who came to the area visit were students $(\mathrm{BSc}, \mathrm{MSc}, \mathrm{PhD}, n=34), 62.2 \%$ were working (public and private, $n=100), 12.4 \%$ were retired $(n=20), 4.3 \%$ were unemployed $(n=7)$. In total, $52.2 \%(n=84)$ of the respondents came from Bartın and $47.8 \%(n=77)$ from outside Bartın. Moreover, it was seen that the participation from inside Bartın $(63.2 \%, n=48)$ was higher for men than outside of Bartın $(36.8 \%, n=28)$. In women, participation from outside Bartın $(57.6 \%, n=49)$ was higher than from inside Bartın $(42.4 \%, n=36)$. The distribution regarding the place of origin of the participants in terms of the gender and education level was as in Figure 6.

When the state of being familiar with geological diversity, geoconservation and geoheritage phenomena was examined, it was seen that $59.0 \%(n=95)$ of the participants knew all the concepts and $18.6 \%(n=30)$ knew one or two of the concepts, but $22.4 \%(n=36)$ did not know any of the concepts. Concept familiarities in terms of participant gender are illustrated in Figure 7. According to this figure, at least one concept was known by $43.47 \%$ of female $(n=70)$ and $34.16 \%$ of male participants $(n=55)$. Female participants $(36.02 \%$, $n=58$ ) were much more familiar with all concepts (geological diversity, geoconservation and geoheritage phenomena) than male participants $(22.98 \%, n=37)$. 
Table 1. SWOT analysis.

\begin{tabular}{|c|c|c|c|}
\hline Strengths & Weaknesses & Opportunities & Threats \\
\hline $\begin{array}{l}\text { - } \quad \text { High geodiversity } \\
\text { (Inter)national } \\
\text { geological significance } \\
\text { Promotion of } \\
\text { cultural heritage } \\
\text { GBCs are visible from the 1st } \\
\text { Degree Archaeological Site } \\
\text { located in the north of the } \\
\text { area on the } \\
\text { Güzelcehisar coast } \\
\text { The fact that Güzelcehisar } \\
\text { coast is a natural beach } \\
\text { The area has } \\
\text { ecotourism potential } \\
\text { Having rural } \\
\text { landscape features } \\
\text { Presence of the 1st Natural } \\
\text { Protected Area } \\
\text { in Güzelcehisar } \\
\text { Existence of large forest areas } \\
\text { Microclimatic effect } \\
\text { in Güzelcehisar } \\
\text { GBCs are one of the rare } \\
\text { formations in the world } \\
\text { The rural identity of } \\
\text { Güzelcehisar has the } \\
\text { potential to contribute to } \\
\text { rural development } \\
\text { Local people's income } \\
\text { from tourism } \\
\text { The rural identity of } \\
\text { Güzelcehisar village } \\
\text { Educational and scientific } \\
\text { research materials }\end{array}$ & $\begin{array}{l}\text { Lack of land access to } \\
\text { whole GBCs } \\
\text { Ensuring accessibility } \\
\text { to GBCs only by } \\
\text { seaway connection } \\
\text { - Continuation of GBCs along } \\
\text { the open sea (extend to } \\
\text { Mugada Bay) } \\
\text { The realization of tourism } \\
\text { activity only in } \\
\text { summer months } \\
\text { The limited carrying capacity } \\
\text { of the Güzelcehisar coast } \\
\text { Few training courses } \\
\text { for guides } \\
\text { Lack of promotion for } \\
\text { Güzelcehisar village } \\
\text { Does not take part in the } \\
\text { tourism network }\end{array}$ & $\begin{array}{l}\text { - Güzelcehisar coast } \\
\text { is already } \\
\text { attracting great } \\
\text { attention in terms } \\
\text { of sea tourism } \\
\text { - Local } \\
\text { administrations } \\
\text { support the studies } \\
\text { on the promotion } \\
\text { of GBCs } \\
\text { Good public } \\
\text { accessibility } \\
\text { Services to support } \\
\text { coastal geotourism }\end{array}$ & $\begin{array}{l}\text { The obstacle to the } \\
\text { access of GBCs due } \\
\text { to adverse weather } \\
\text { conditions that may } \\
\text { occur in the open sea } \\
\text { Problems arising } \\
\text { from overuse in } \\
\text { summer months due } \\
\text { to excessive use } \\
\text { Intensive use due to } \\
\text { sea tourism }\end{array}$ \\
\hline
\end{tabular}

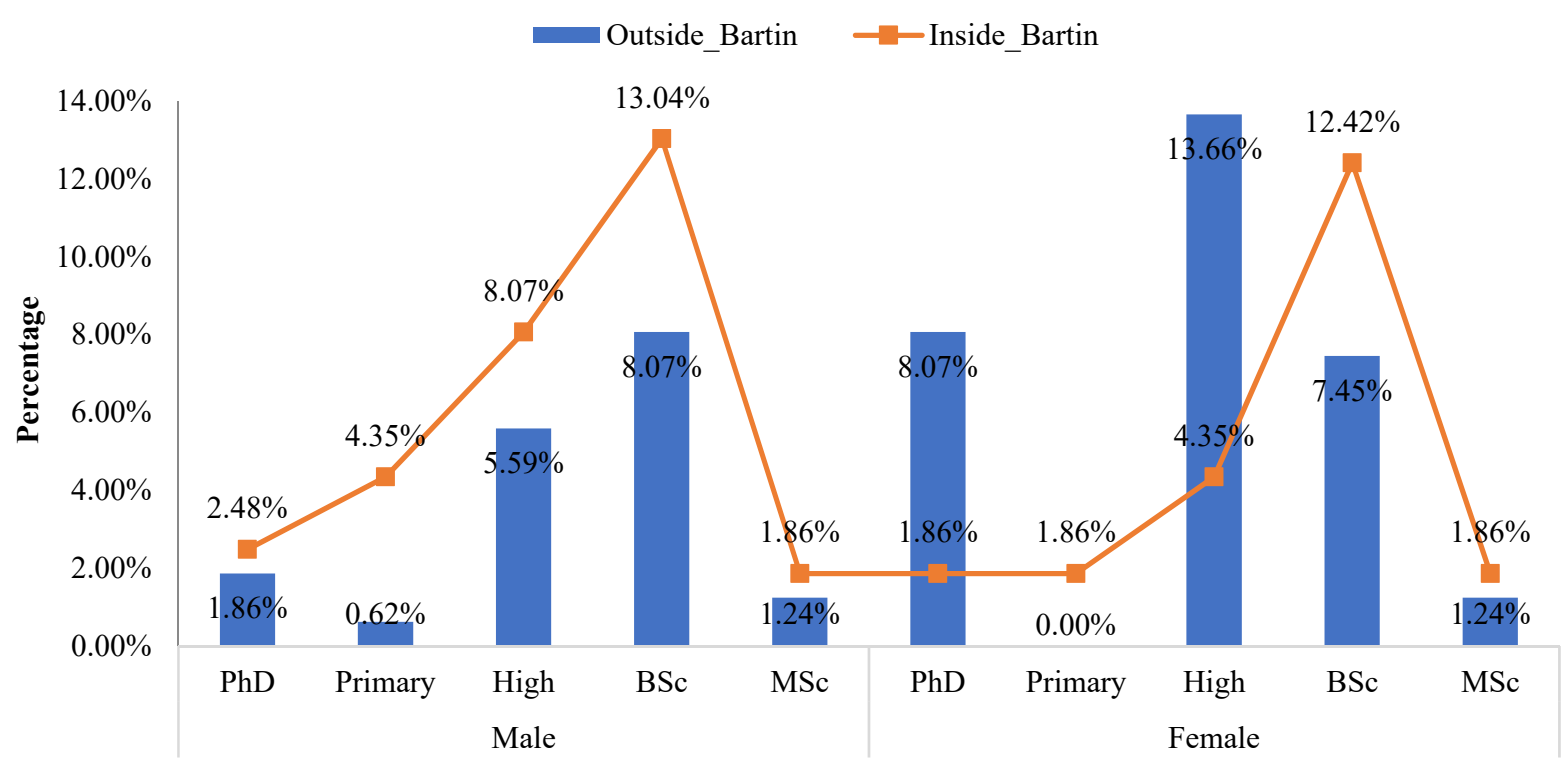

Figure 6. Place of origin in terms of gender and education level. 


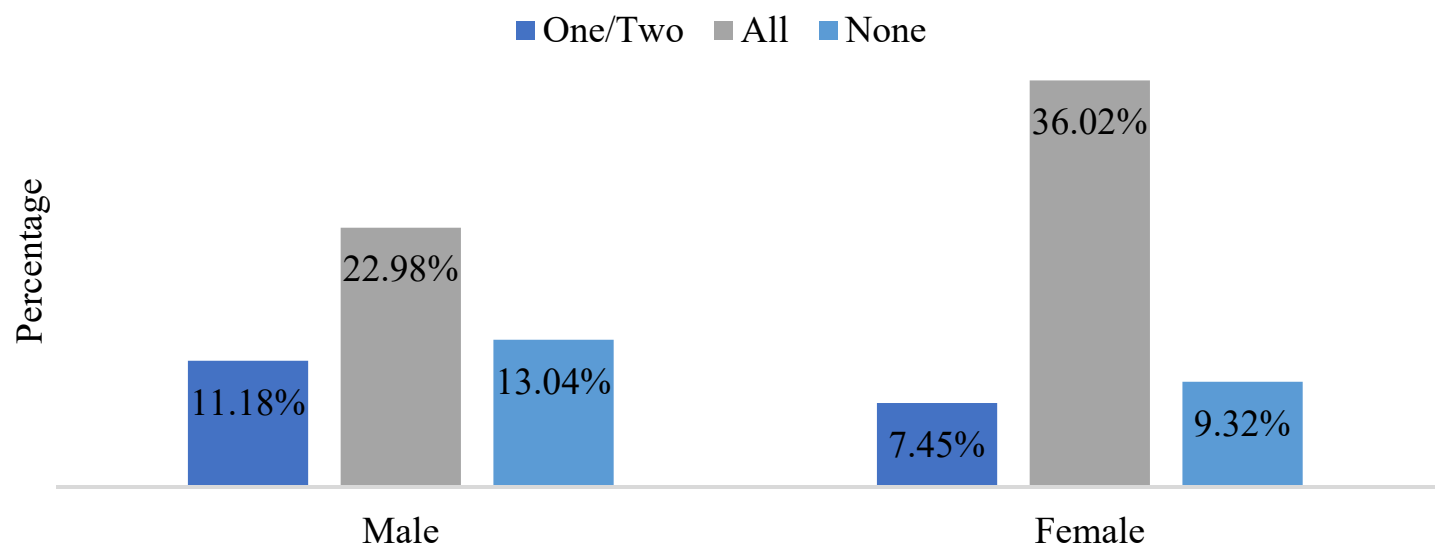

Figure 7. Concept familiarities in terms of gender.

A total of $62.1 \%(n=100)$ of the participants visited Güzelcehisar with the recommendation of an acquaintance. Of the rest, $6.2 \%$ came to visit because of the media and brochures $(n=10)$, and $31.7 \%$ for other reasons (business and hometown visits, $n=51$ ). Area visit activities take place in two dimensions: social (walking, swimming, photographing, climate-based social activities and others) and cultural (Basalt columns, touristic aspect and scientific purposes). An amount of $65.2 \%$ of the participants visited the site for a social activity $(n=105)$, and $34.8 \%$ for a cultural activity $(n=56)$. The cultural activity dimension was in the second place for $23.8 \%(n=25)$ of those who visited the area primarily for social activities. For $57.1 \%(n=32)$ of those whose primary purpose was cultural activity, the secondary visit dimension was social activity. In the eyes of the participants, the features of Güzelcehisar that are worth preserving were discussed in two dimensions: Geology (Basalt columns) and other (landscape, forest, etc.). The geology (Basalt columns) of Güzelcehisar for $9.9 \%(n=16)$ of the participants who came to the site visit, and other features for $90.1 \%(n=145)$ were the features worth preserving in the first place. In total, $18.8 \%(n=3)$ of those who stated the geology of the area (Basalt columns) as a priority feature stated other features as the second reason for protection. On the other hand, 40.7\% $(n=59)$ of those who stated other features of the area as the primary reason for protection indicated Basalt columns (geology of the area) as a secondary protection reason. According to the participants, the order of importance (first three preferences) for the natural and cultural features of Güzelcehisar was as in Figure 8. The natural and cultural features that had priority in the first, second and third preference rankings were the Basalt columns $(66.5 \%$, $n=107)$, marine assets $(40.4 \%, n=65)$ and forest assets $(29.2 \%, n=47)$, respectively.

- First $\quad$ Second $\quad$ Third

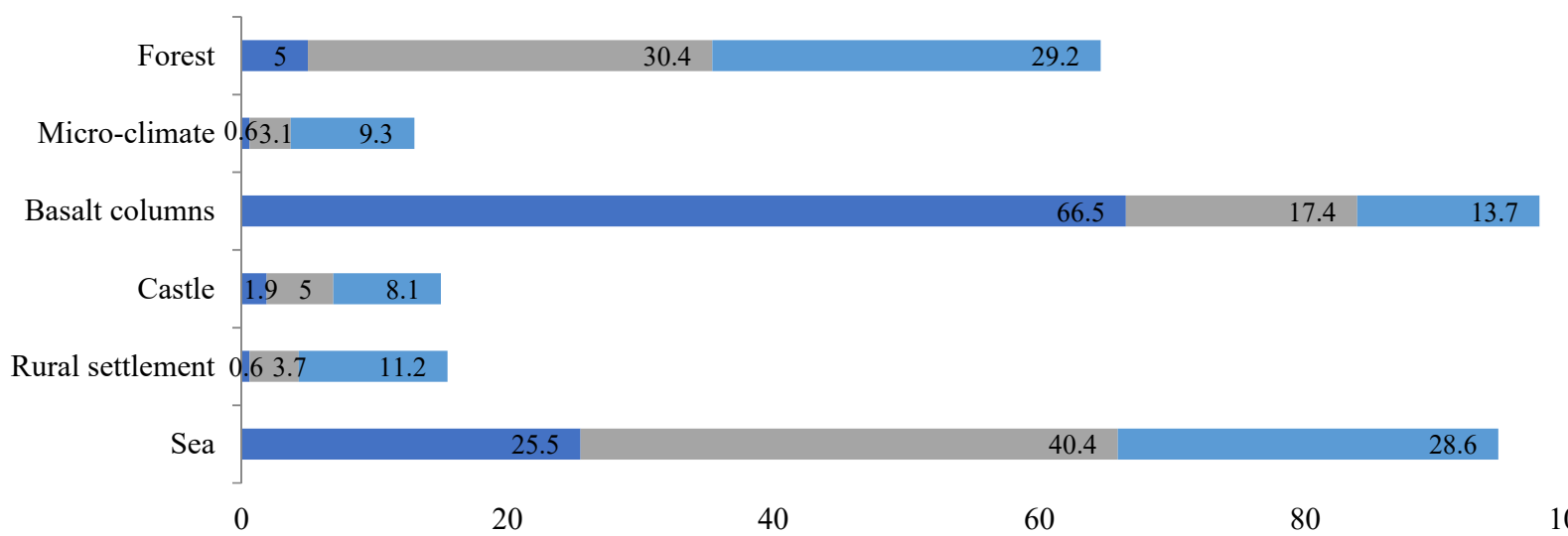

Figure 8. According to the participants, the natural and cultural features of the area in order of priority. 
According to the preference order of the participants, the first choice was the rare geological formation that came to mind when the GBCs were mentioned $(58.4 \%, n=94)$, the second was tourism and recreation potential $(28.0 \%, n=45)$, and the third was coastal geotourism $(20.5 \%, n=33)$ (Figure 9$)$.

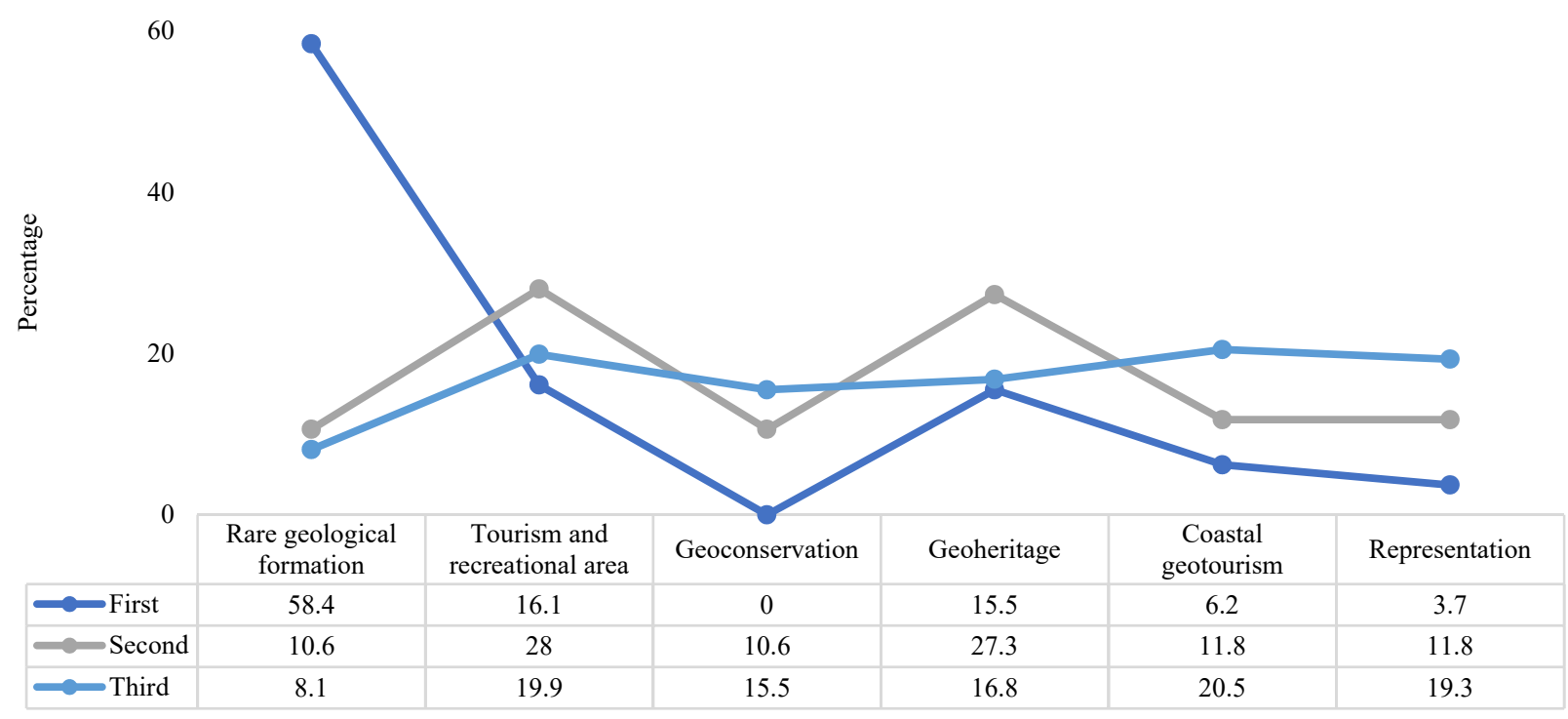

Figure 9. The distribution of the first features that come to mind when GBCs is mentioned.

The scientific value represented by basalt columns was the geological heritage of $52.2 \%$ $(n=84)$ of the participants, $27.3 \%(n=44)$ visual and aesthetic value, $14.9 \%(n=24)$ of the coastal geotourism value and $5.6 \%(n=9)$ determined it as having geoconservation value.

For the participants who wanted to have detailed information about the area, the priority according to the first, second and third preference order were, respectively, walking with the guide $(41.6 \%, n=67)$, the introductory booklet $(23.0 \%, n=37)$ and information board $(24.8 \%, n=40)$. In this context, the distribution of the information tools preferred by the participants is given in Figure 10.

45

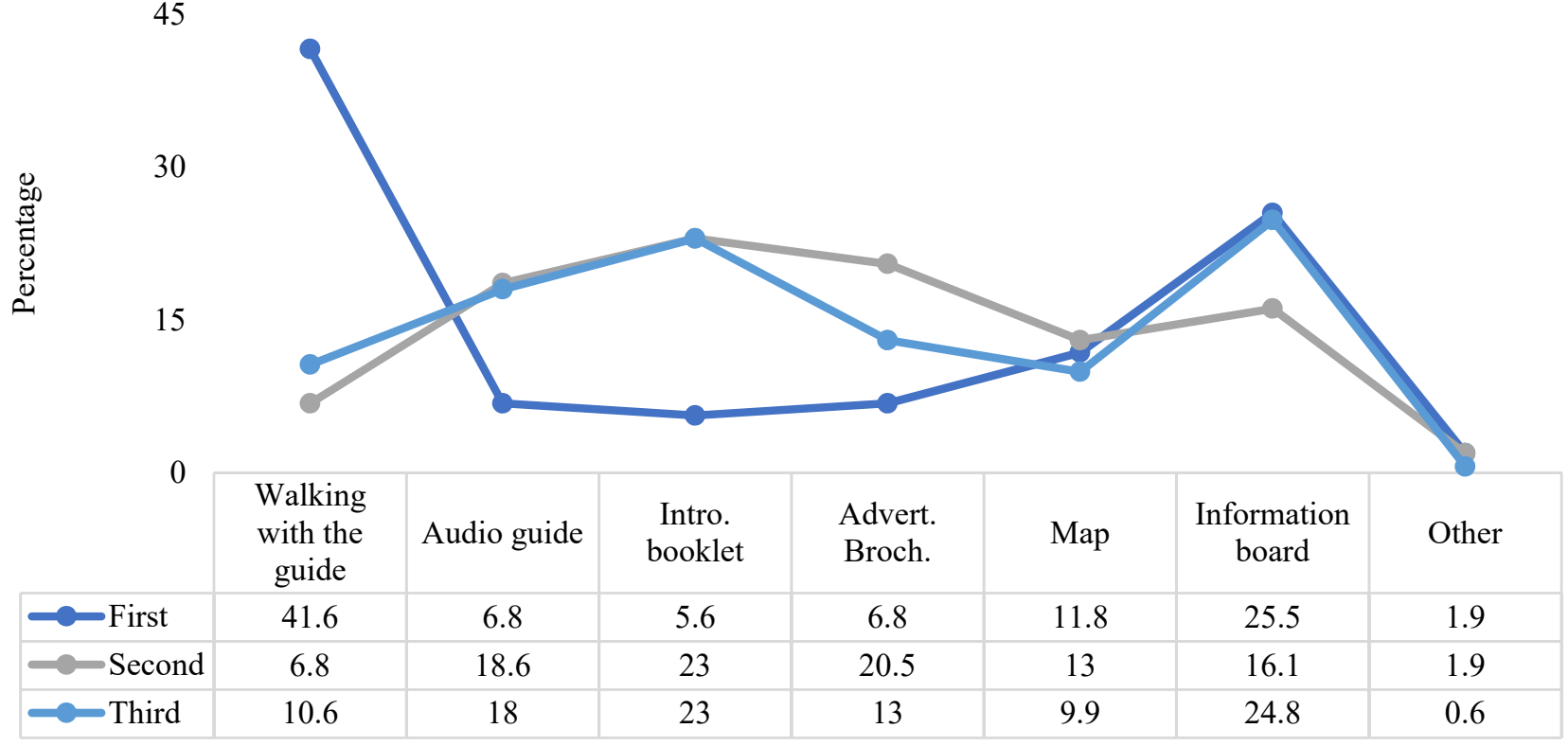

Figure 10. Preferred information tools for detailed information on basalt columns. 
A total of $67.1 \%(n=108)$ of the participants visited with their family, $31.7 \%(n=51)$ with their friend and $1.2 \%(n=2)$ came to visit alone. In addition, $52.8 \%(n=85)$ of the participants visited Güzelcehisar five or more times, 28.0\% $(n=45)$ visited Güzelcehisar two to four times and $19.2 \%(n=31)$ once. The time spent visiting Güzelcehisar was $151 \mathrm{~min}$ and more $(47.2 \%, n=76), 61-90 \mathrm{~min}(18.6 \%, n=30), 121-150 \min (14.3 \%, n=23)$, $31-60 \min (12.4 \%, n=20)$ and $91-120 \min (7.5 \%, n=12)$.

An amount of $57.8 \%(n=93)$ of the participants preferred to visit the field in spring, $39.7 \%(n=64)$ in summer, $1.9 \%(n=3)$ in autumn and $0.6 \%(n=1)$ in winter. With a low rate of $2.5 \%(n=4)$, the participants conducted the field visits in the autumn and winter seasons. The visit time schedule for the seasons, times and durations of the site visit was as in Figure 11.
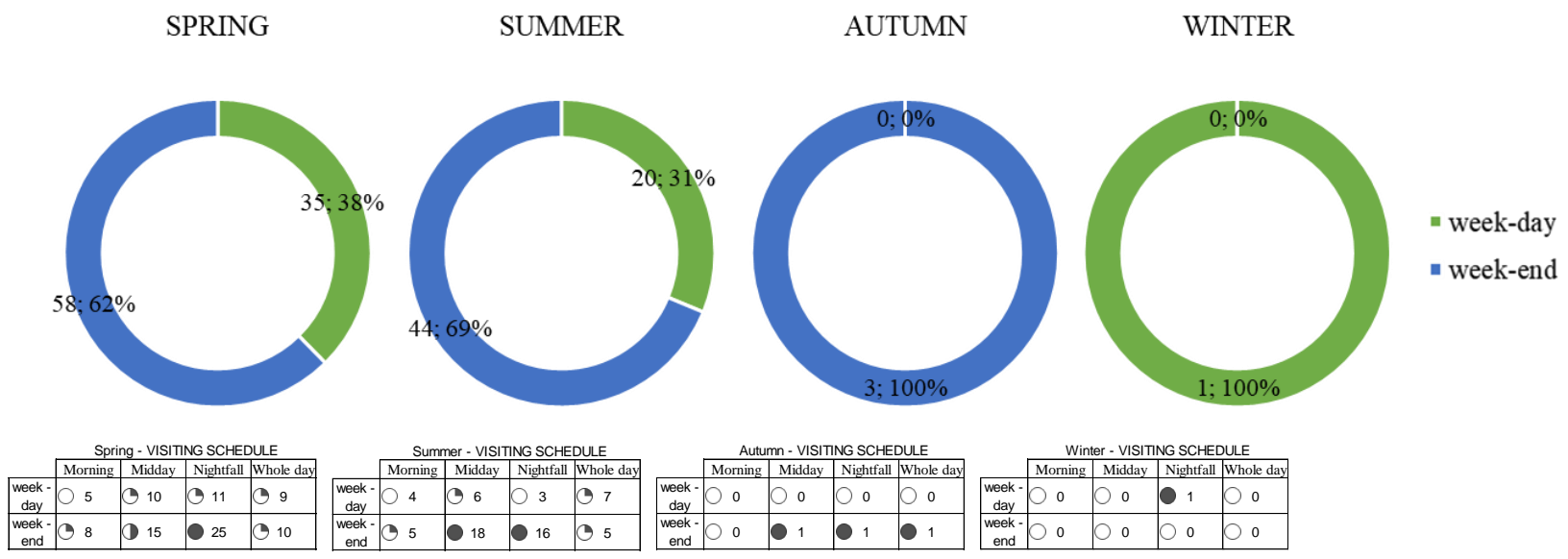

Figure 11. Season-visiting schedule of participants.

The distribution of the responses given to the five-point Likert questions about GBCs of the survey is shown in Figure 12. Accordingly, 97.5\% $(n=157)$ of the participants stated that Güzelcehisar basalt columns were visually appealing (Q23.1), 80.1\% $(n=129)$ were accessible (Q23.2), 98.8\% $(n=159))$ to have unique/rare natural features (Q23.3), 82.0\% $(n=132)$ to have a safe visiting environment $(\mathrm{Q} 23.4)$ and $49.1 \%(n=79)$ to be able to obtain information about the rocks during the visit (Q23.5), and stated that they agreed with their situation.

$\square$ Strongly disagree $\square$ Disagree $\quad$ Neither agree nor disagree $\quad$ Agree $\square$ Strongly agree

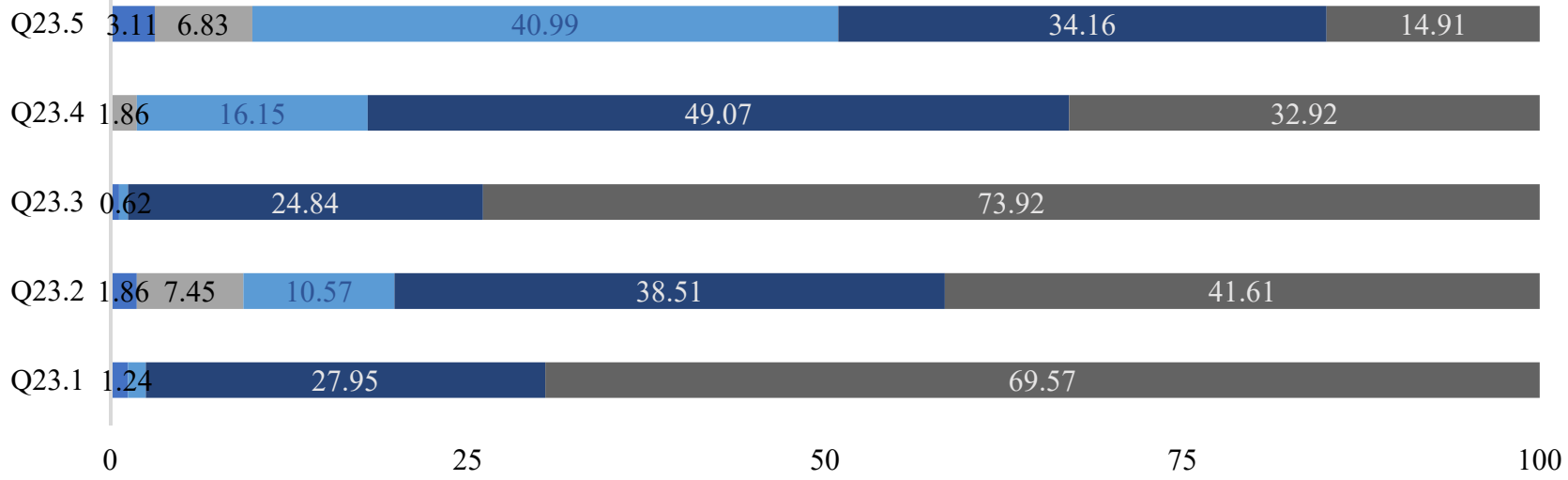

Figure 12. Factors of a visit to Güzelcehisar basalt columns $\rightarrow$ Cronbach $\alpha$-coefficient $=0.618$ (Cronbach $\alpha>0.60$ [57]).

There were 89 participants $(55.3 \%)$ who noticed the information boards regarding the GBCs, and 72 participants $(44.7 \%)$ who did not. In total, $83.2 \%(n=74)$ of the 89 participants who noticed the information boards stated that they learned new information from the 
boards, and $93.3 \%(n=83)$ stated that the information was completely/partially sufficient. In addition, information that 26 participants (29.2\%) who noticed the information boards wanted to see on the boards was (i) information about the geological formation/rocks about the basalt layers $(42.3 \%, n=11)$, (ii) Geomorphological information about the basalt columns $(38.5 \%, n=10)$, (iii) general information about the flora and fauna in the basalt columns $(11.5 \%, n=3)$ or (iv) all of the items given in i-iii $(7.7 \%, n=2)$. An amount of 77 participants $(86.5 \%)$ who paid attention to the panels during the field visit, found the information given on the information boards about the basic processes and geological factors in the formation of GBCs understandable.

The primary factors in the first, second and third preference rankings for visiting Güzelcehisar during the COVID-19 pandemic process were few visitors $(39.8 \%, n=64)$, being near to the sea in a rural environment $(25.5 \%, n=41)$ and the wooden boardwalk for walkability $(22.4 \%, n=36)$. The distribution of factors related to field visits during the COVID-19 pandemic process in terms of the first three preference orders is shown in Figure 13.

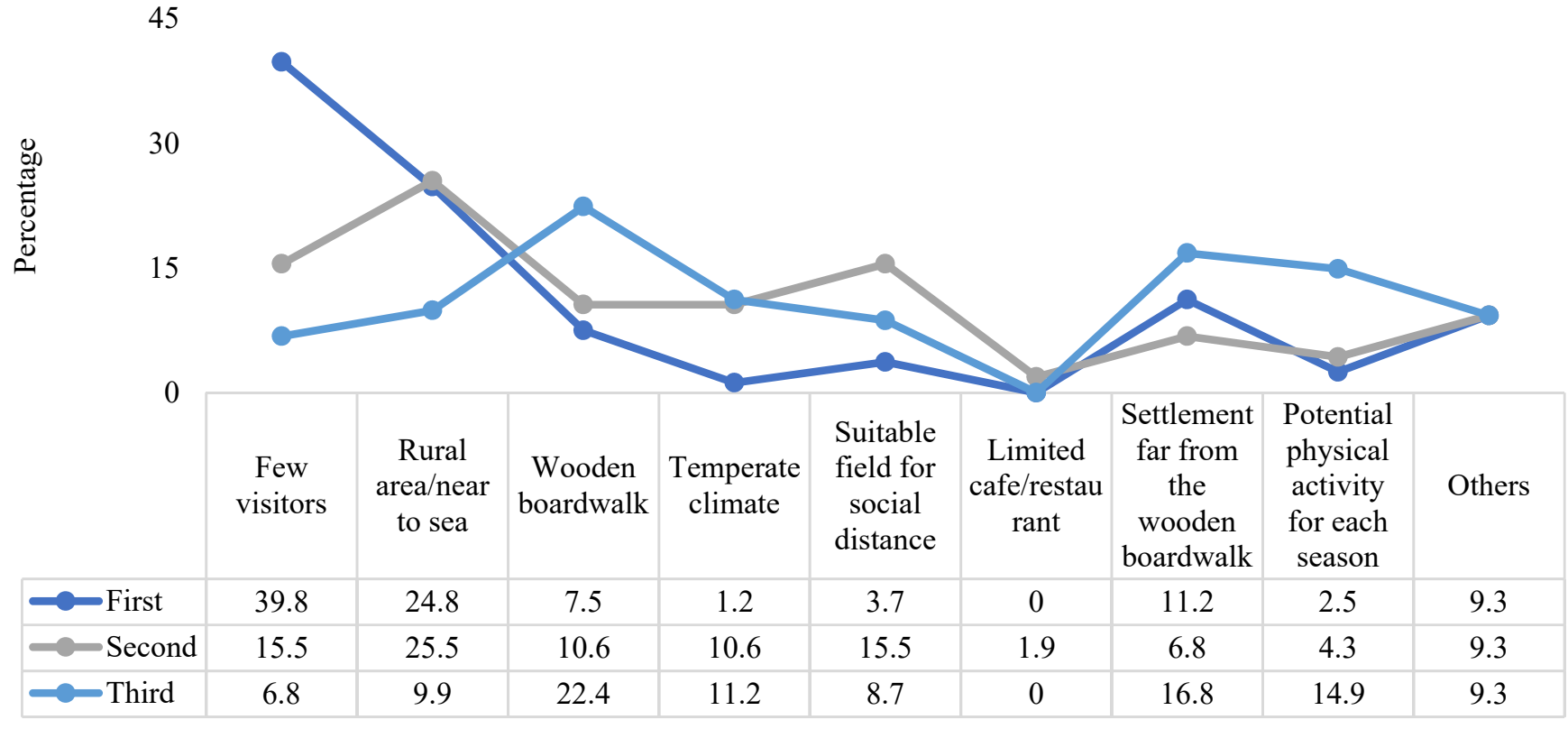

Figure 13. The first three choices of factors related to field visit during the COVID-19 pandemic process.

The reasons for visiting GBCs were of two dimensions: recreational and cultural factors. In the recreational factors, there were discovering new places (rf-1: discovering new places), rest/relaxation (rf-2: rest/relaxation), having time away from daily routine (rf-3: escape from daily routine), physical and spiritual renewal (rf-4: physical and spiritual renewals), passing very happy hours (rf-5: passing very happy hours) and integration with nature (rf-6: commune with nature); in the cultural factors, there were sub-dimensions of acquiring new information (cf 1: learning new information), examining/learning geological formations (cf-2: obtain information about geological formation) and conducting scientific research (cf-3: scientific research). In terms of preference order: recreational factors-first preference $96.9 \%(n=156)$, second preference $86.3 \%(n=139)$ and third preference $93.2 \%$ $(n=150)$; cultural factors-first preference $3.1 \%(n=5)$, second preference $13.7 \%(n=22)$ and third preference $6.8 \%(n=11)$. The distribution of recreational and cultural factors together with their sub-dimensions in terms of preference order was as in Figure 14.

The impressions of the participants after the field visit were discussed in two dimensions as Güzelcehisar and GBCs. In Güzelcehisar impressions-Gi-1: impressive landscape; Gi-2: impressive coastal cliff; Gi-3: a quiet place; Gi-4: wooden boardwalk. GBCs impressions included: GBCi-1: rock characteristic; GBCi-2: impressive cave; GBCi-3: environmental education sub-dimensions. In terms of preference order: Güzelcehisar impression-first 
preference $80.7 \%(n=130)$, second preference $55.3 \%(n=89)$ and third preference $66.5 \%$ ( $n=107)$; dimension GBCs impression-first preference: $19.3 \%(n=31)$, second preference: $44.7 \%(n=72)$ and third preference $33.5 \%(n=54)$. The distribution of Güzelcehisar and GBCs impressions with their sub-dimensions in order of preference was as in Figure 15.

$\square$ First $\quad$ Second $\square$ Third

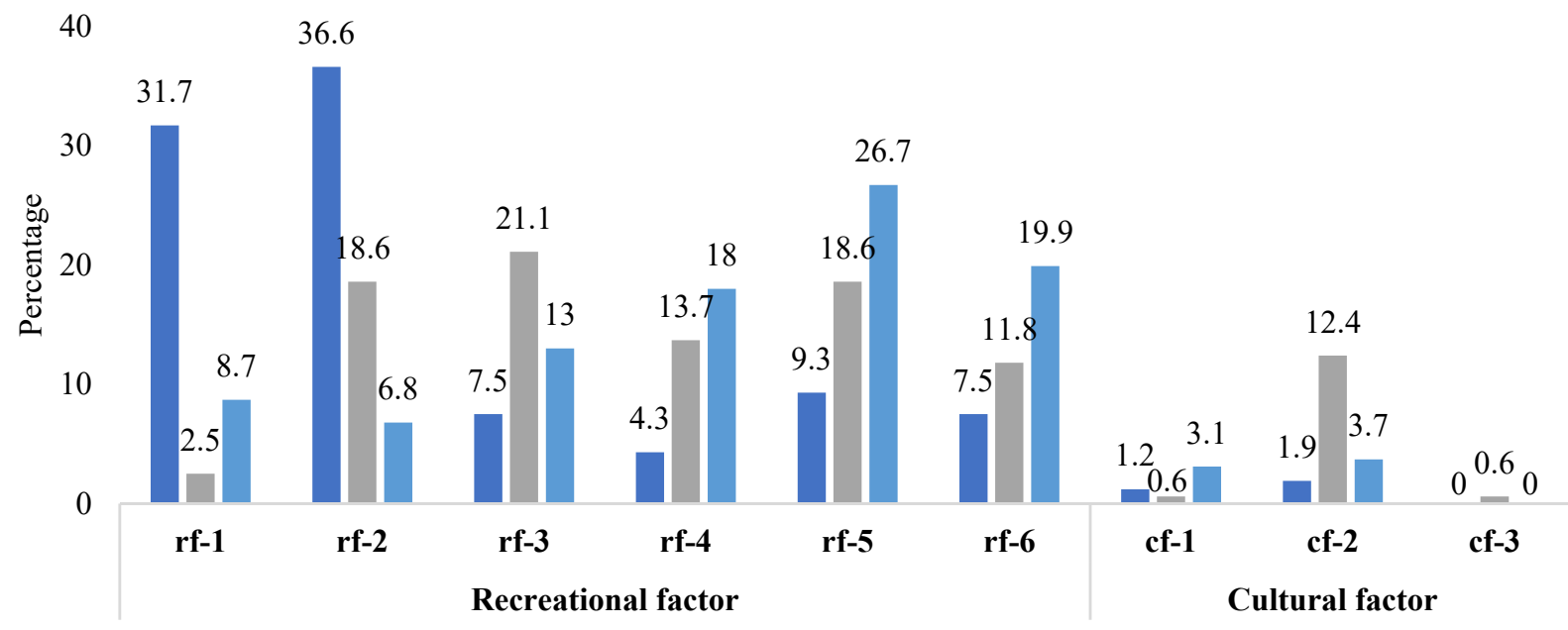

\begin{tabular}{|l|l|}
\hline rf-1: Discovering new places & cf-1: Learning new information \\
rf-2: Rest/relaxation & cf-2: Obtain information about ge- \\
rf-3: Escape from daily routine & ological formation \\
rf-4: Physical and spiritual renewals & cf-3: Scientific research \\
rf-5: Passing very happy hours & \\
rf-6: Commune with nature &
\end{tabular}

Figure 14. Reasons for GBCs visits in order of preference.

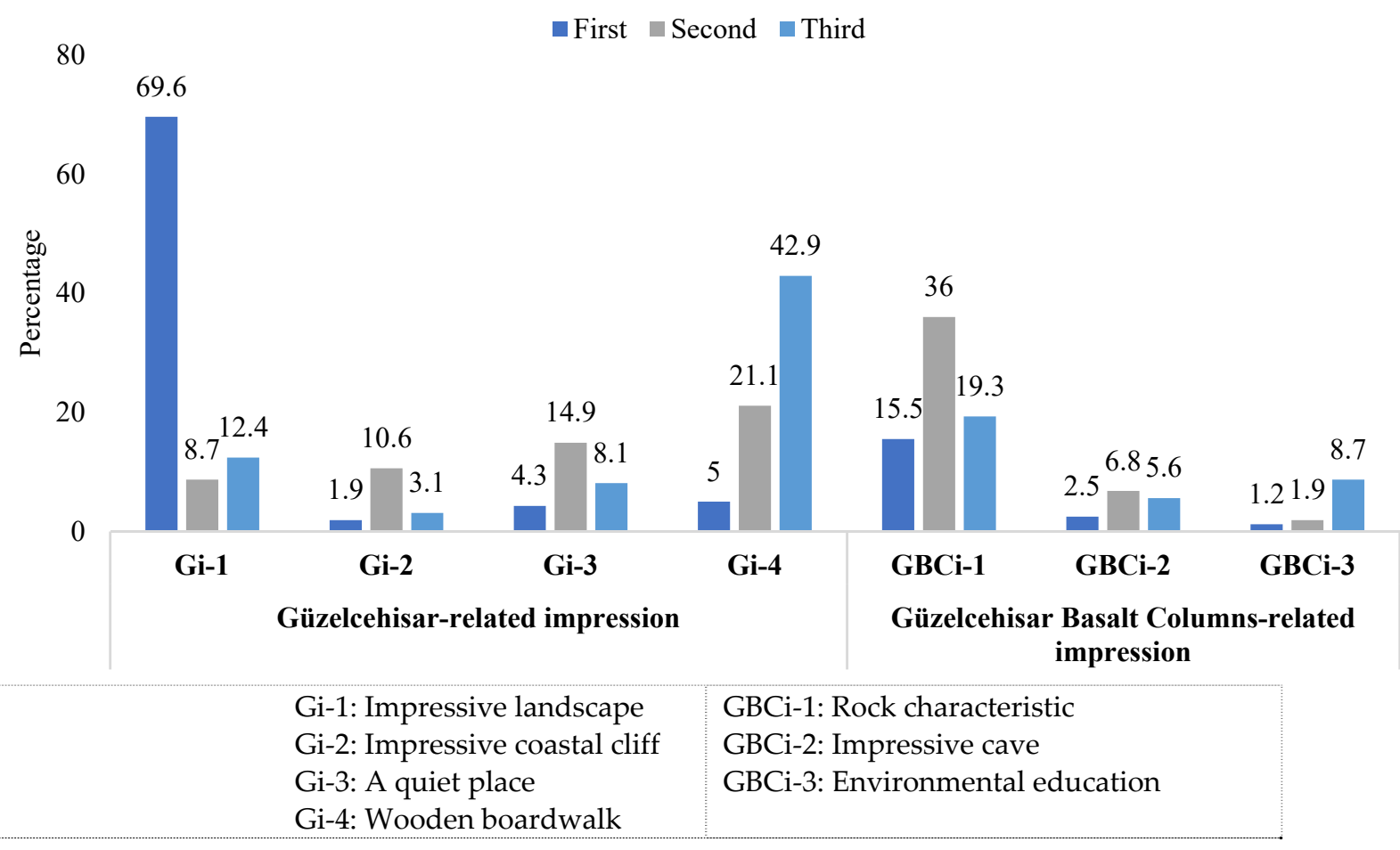

Figure 15. Impressions after the GBCs visit in terms of preference order. 
The memorable aspects of the GBCs visit of the participants were discussed in two dimensions: GBCs and Güzelcehisar-related. The distribution of the memorable elements of the visitors about GBCs and Güzelcehisar were as in Figure 16. In terms of preference order, the memorable ones specific to GBCs were $73.9 \%(n=119), 25.5 \%(n=41)$ and $32.9 \%$ ( $n=53)$, respectively, according to the first, second and third preference order; Güzelcehisarspecific recalls were $26.1 \%(n=42), 74.5 \%(n=120)$ and $67.1 \%(n=108)$, respectively, in the same order of preference.

$\square$ First $\square$ Second $\square$ Third

50

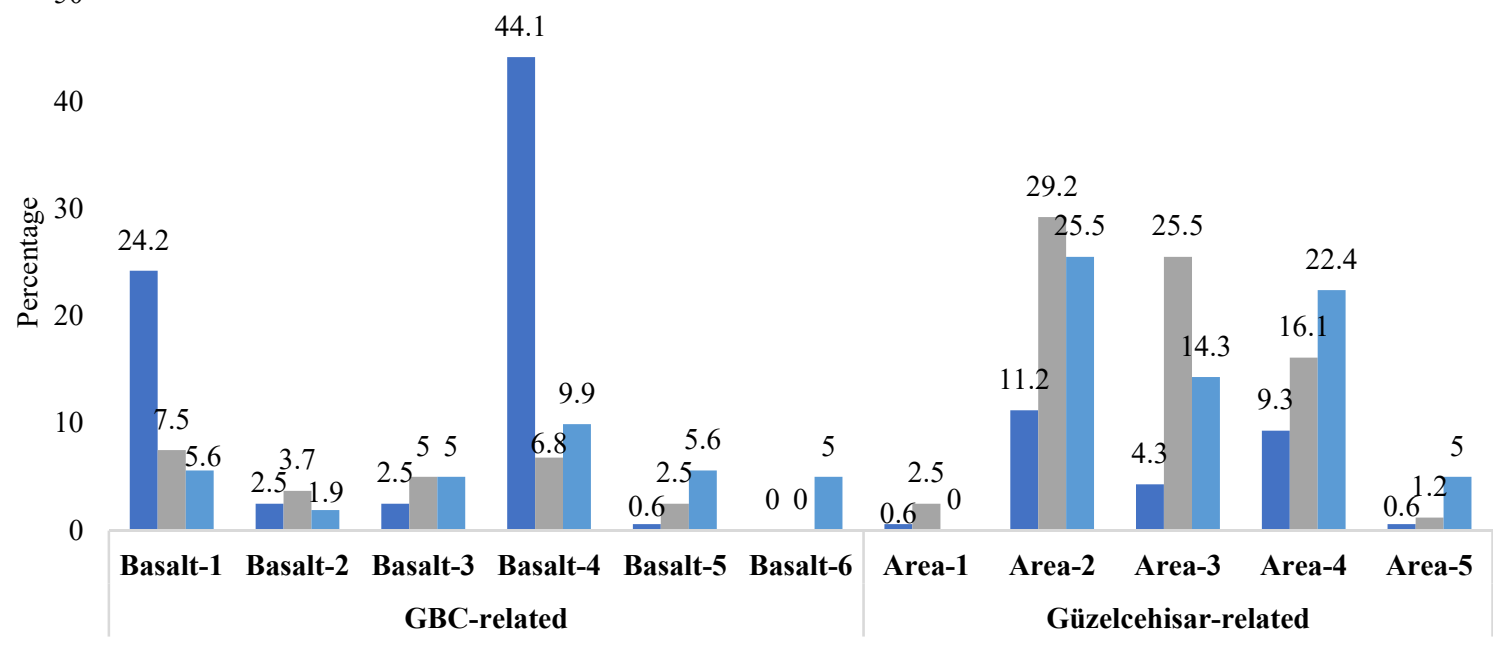

\begin{tabular}{|l|l|}
\hline Basalt-1: Rock & Area-1: Information board \\
Basalt-2: Rock color & Area-2: Wooden boardwalk \\
Basalt-3: Plants on rock & Area-3: Viewing platforms of boardwalk \\
Basalt-4: Rock array & Area-4: Synergy of rock and sea \\
Basalt-5: Island between rocks & Area-5: Limited visual and physical accessibil- \\
Basalt-6: Secret cave between rocks & ity due to synergy of rock-sea \\
\hline
\end{tabular}

Figure 16. Distribution of the memorable elements of the visitors about GBCs and Güzelcehisar.

The distribution of recreational activities performed together with the GBCs visit in terms of preference order is shown in Figure 17. Accordingly, in the first, second and third preferences, the most recreational activities performed by the participants by visiting the GBCs were walking $(35.4 \%, n=57)$, taking photos $(35.4 \%, n=57)$ and nature observation $(33.5 \%, n=54)$, respectively.

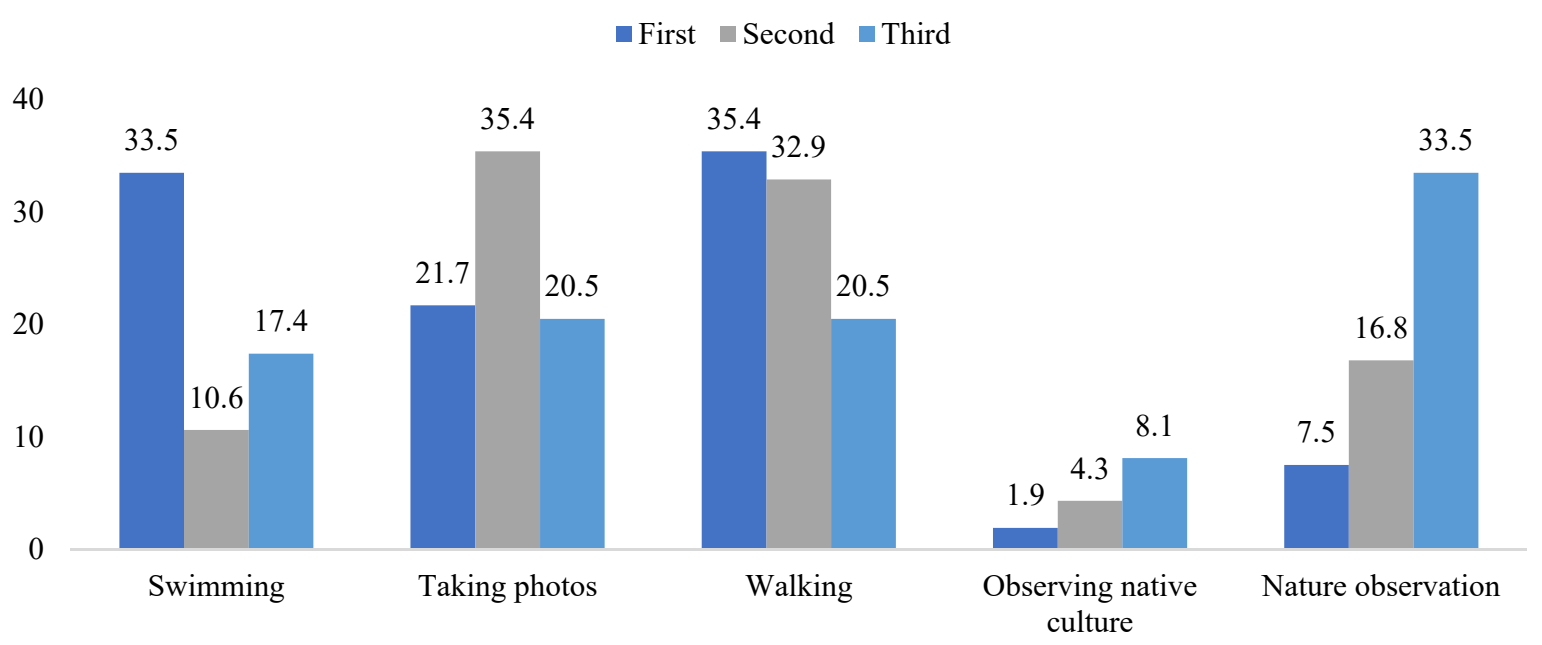

Figure 17. Recreational activities carried out together with the GBCs visit in terms of preference order. 
It was seen that there were 152 participants (94.4\%) who were positively compatible with the image created by the GBCs and their impressions after the area visit.

\subsection{Chi-square Test Results}

The Chi-square independence test was used to determine whether there was a statistically significant association between the demographic characteristics (gender, education, residence) of the participants who came to the site visit, and the factors affecting the site visit and ones perceived afterwards. Findings for pairs of questions with a statistically significant association ( $p$-values $<0.05$ ) are summarized in Table 2. Chi-square independence tests and heatmap graphics were created with the codes written in the MATLAB R2019b program.

There was a statistically significant association between education levels and the knowledge of geological concepts (geological diversity, geoconservation and geoheritage) $(p=0.000)$. In terms of visitor education levels, the distributions of being familiar with all, one/two concepts and not being familiar with any of the concepts were $81.1 \%(n=77)$, $46.7 \%(n=14)$ and $22.2 \%(n=8)$ for those with at least a bachelor's degree, and $18.9 \%$ $(n=18), 53.3 \%(n=16)$ and $77.8 \%(n=28)$ for those with high school and below, respectively.

There was a statistically significant association between the visitor residence status (in/out of Bartın) and the visit purpose $(p=0.000)$. In total, $81.0 \%(n=68)$ and $48.1 \%$ $(n=37)$ inside and outside Bartın participants visited Güzelcehisar for social activities. An amount of $19.0 \%(n=16)$ and $51.9 \%(n=40)$ inside and outside Bartın participants visited Güzelcehisar for cultural activities.

There was a statistically significant association between the visitor residence status (in/out of Bartın) and the status of obtaining information about the rocks during the visit $(p=0.024)$. In terms of the visitor residence status, distributions of visitors regarding their level of information acquisition (agreeing, undecided and disagreeing) during the visit were $62.0 \%(n=49), 39.4 \%(n=26)$ and $56.25 \%(n=9)$ for inside Bartın visitors, and 38.0\% $(n=30), 60.6 \%(n=40)$ and $43.75 \%(n=7)$ for outside Bartın visitors, respectively.

When the reasons for visiting the GBCs were examined, it was seen that recreational factors (first choice: $96.9 \%(n=156)$; second choice: $86.3 \%(n=139)$; third choice: $93.2 \%$ $(n=150))$ were preferred more than cultural factors (first choice: $3.1 \%(n=5)$; second choice: $13.7 \%(n=22)$; third choice: $6.8 \%(n=11))$. A statistically significant association was found between the visitor residence status (in/out of Bartın) and the reasons for visiting the GBCs in the second preference order $(p$-value $=0.040)$. In total, 91.7\% $(n=77)$ and $80.5 \%(n=62)$ inside and outside Bartın participants visited Güzelcehisar for recreational activities, and $8.3 \%(n=7)$ and 19.5\% $(n=15)$ inside and outside Bartın participants for cultural activities, respectively. A statistically significant association was found between the visitor education levels and the reasons for visiting the area in the second preference order ( $p$-value $=0.035)$. In terms of education levels, the visitor distributions in recreational and cultural activities were $58.3 \%(n=81)$ and $81.8 \%(n=18)$ for those with at least a bachelor's degree, and $41.7 \%$ $(n=58)$ and $18.2 \%(n=4)$ for those with high school and below, respectively.

A statistically significant association was found between the visitor residence status (in/out of Bartın) and the memorable aspects of the area visit ( $p$-value $=0.004)$. A total of $64.3 \%(n=54)$ and $84.4 \%(n=65)$ inside and outside Bartın visitors had GBC-related memorable aspects, while $35.7 \%(n=30)$ and $15.6 \%(n=12)$ visitors had Güzelcehisarrelated memorable aspects, respectively.

A statistically significant association was found between the visitor education level and GBC-related scientific value $(p$-value $=0.003)$. In terms of visitor education levels, distributions of visual aesthetics, geo-conservation, geoheritage and geotourism values were $38.6 \%(n=17), 66.7 \%(n=6), 69.1 \%(n=58)$ and $\% 75.0(n=18)$ for those with at least a bachelor's degree, and $61.4 \%(n=27), 33.3 \%(n=3), 30.9 \%(n=26)$ and $25.0 \%(n=6)$ for those with high school and below, respectively. 
Table 2. Statistical result of area visit $(p<0.05)$.

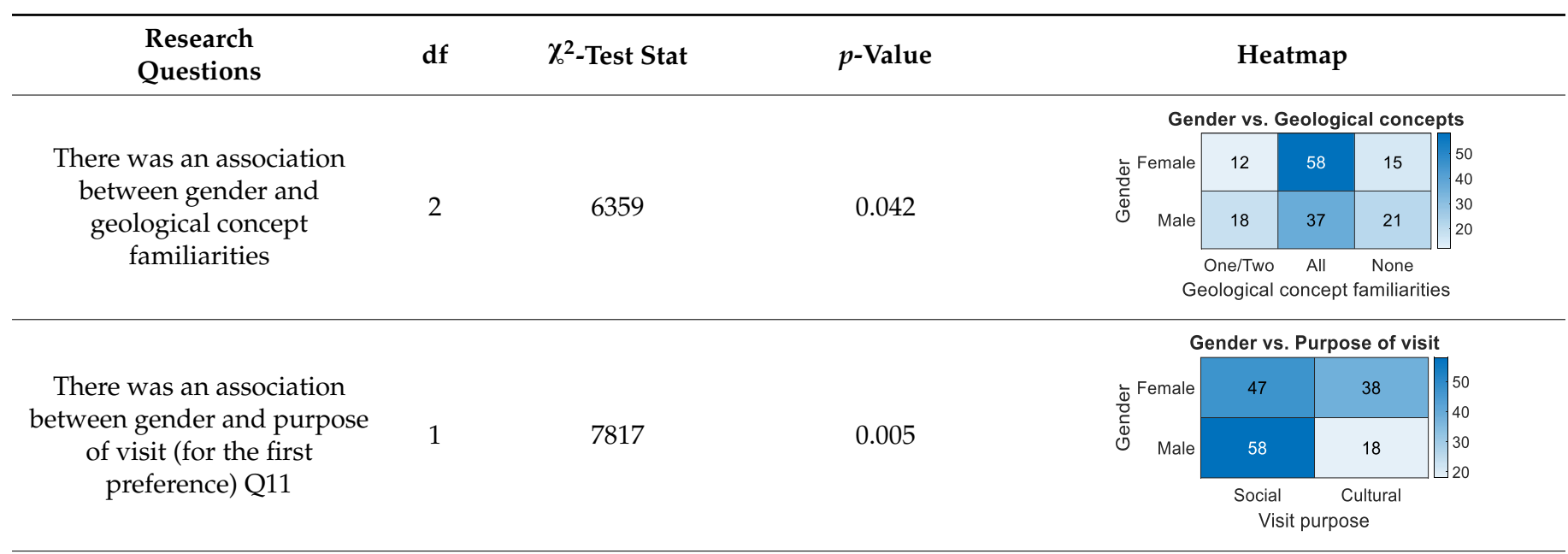

There was an association between gender and recreative activities with GBCs visit (for the first preference) Q33.1
3

16,436

0.001

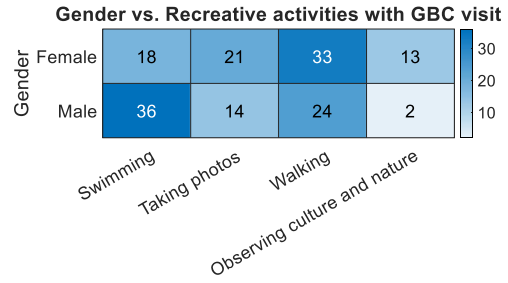

Recreative activities with $\mathrm{GBC}$ visit

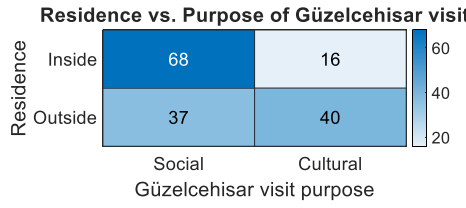

There was an association between residence and Q23.5 (obtaining information about the rocks during the visit)

There was an association between residence and visit impression (for the second 1 4231 0.040 preference) Q30.2
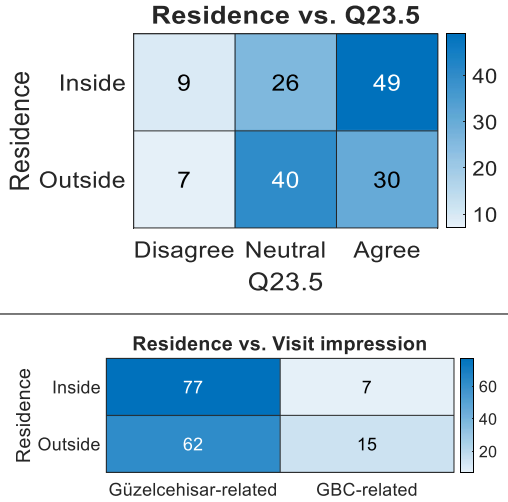

$$
\text { Visit impression }
$$

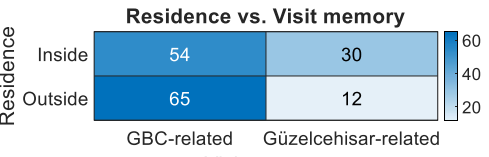

Visit memory
There was an association between residence and visit memory (for the first preference) Q32.1
1

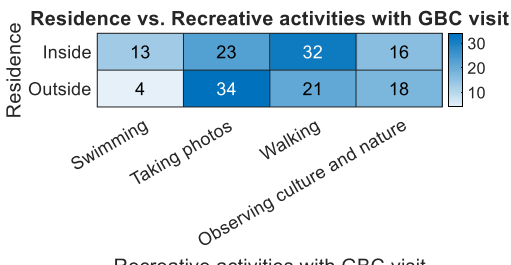

39001

0.029
There was an association between residence and recreative activities with GBCs visit (for the second preference) Q33.2 
Table 2. Cont.

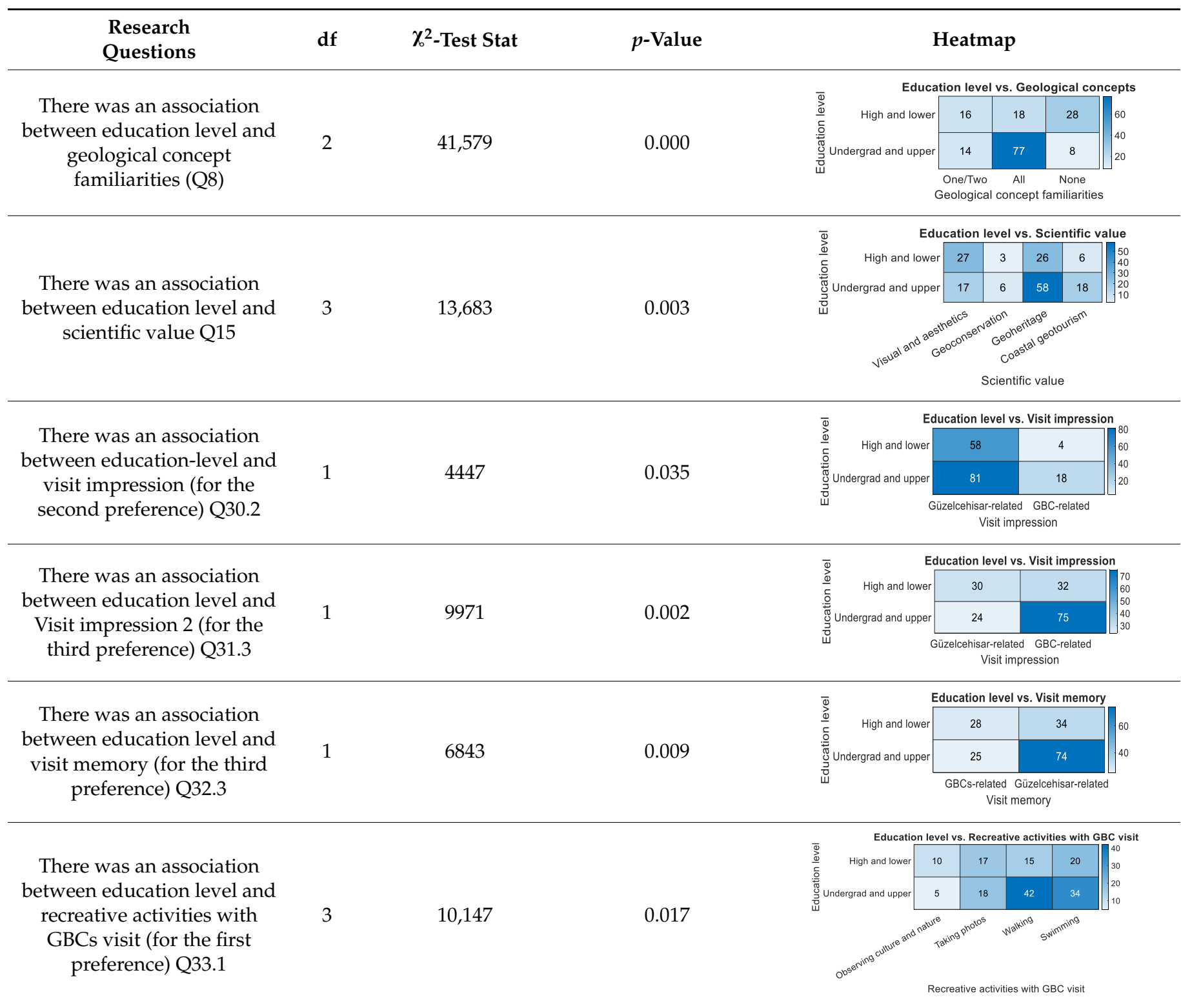

A statistically significant association was found between the visitor education levels and the impressions after visiting GBCs ( $p$-value $=0.002)$. In terms of visitor education levels, distributions of Güzelcehisar- and GBCs-related impressions were $44.4 \%(n=24)$ and $70.1 \%(n=75)$ for those with at least a bachelor's degree, and $55.6 \%(n=30)$ and $29.9 \%$ $(n=32)$ for those with high school and below, respectively.

\section{Discussion and Conclusion}

\subsection{Theoretical Implications}

Tourism and recreation opportunities and practices in rural coastal landscapes are considered as sustainable regional development factors [58]. Rural tourism should be considered as a factor in local development and be encouraged as a vital development objective in order to improve people's quality of life. This type of tourism should also contribute to revitalizing the economy while improving the local population's standard of living [43].

In the research area, which had the Black Sea climate characteristics, intense tourism activities were carried out only in the summer months, depending on the 'sun and sea'. 
Visitors' need to have a more individualized and flexible touristic experience instead of a typical beach holiday increased the interest in nature. More and more people prefer to participate in more active and environmentally friendly tourism that includes new and different activities. Consequently, the demand for rural tourism increased. Different from a more traditional beach holiday, it is possible to de-seasonalize the rural holiday since it does not depend on weather conditions. Likewise, a creative tourist destination does not depend on seasons. Moreover, it's more profitable as such tourists have a higher purchasing power [47]. As a result, it is important to diversify tourism in terms of sustainable development in rural coastal areas, to reduce the strong seasonality of the region and to develop new economies and innovative approaches. In this context, Güzelcehisar is a rural coastal settlement suitable for the development of alternative tourism activities that reduce seasonal dependence and create new opportunities for the Western Black Sea Region. Güzelcehisar, in addition to its basalt columns, is an important coastal settlement on a regional scale with its natural sandy beach, rich forest areas, agricultural product diversity, archaeological values and preserved rural coastal landscape character.

As Štrba [10] pointed out, geosites, as a form of natural heritage, represent integral parts of any tourist destination that contributes significantly to the overall attractiveness of certain areas anywhere in the world. In addition, Keskin Citiroglu [23] emphasized that coastal cliffs are important examples of geological heritage in terms of geological formations and features on the Black Sea coast of Turkey. Keskin Citiroglu [23], the GBCs and the cave formations on the coast highlighted the coastal geotourism potential in the research area. Increasing the awareness of the people living in Güzelcehisar on tourism, conservation and environmental issues and new employment opportunities that coastal geotourism can provide should make positive contributions in terms of sustainable rural development and economic development.

The findings presented in this article provided some empirical evidence for visitors' understanding of "geodiversity", "geoheritage", "geotourism" and "geoconservation". According to visitor data, different levels of understanding and awareness of the terms "geodiversity", "geoheritage" and "geoconservation" were identified. According to the survey findings, the majority of the visitors had a high level of understanding and awareness of the mentioned concepts.

The features of Güzelcehisar worth preserving were discussed in two dimensions: the geology of Güzelcehisar (basalt columns) and other landscape features of Güzelcehisar (landscape feature, forest, castle, rural settlement, etc.). The majority of visitors cited other coastal landscape features as first-line features worth preserving. According to Povilanskas [59], coastal scenery is a determining factor in visitor preferences. In parallel with this, within the scope of the Coastal Scenic Evaluation conducted by Ergin [60] for 34 sample areas determined in the Western Black Sea coastal areas of Turkey, Güzelcehisar coast stands out because of its very well-preserved vegetation and the very good color and clarity of sea water showing. In addition, as Crawford and Black [7] stated in their study, this article also showed that visitors were aware of the conservation value of GBCs and recognize the importance of protecting geodiversity. However, when the other landscape features of Güzelcehisar worth preserving and the protection importance of geological diversity were listed, it was seen that less emphasis was placed on the importance of geodiversity. These findings indicated that there is a clear need for a wider public awareness and understanding of geoconservation for the area. The visitor survey revealed that more information needs to be provided to improve the conservation understanding of GBCs.

GBCs have unique characteristics which make them particularly suitable for coastal geotourism and sustainable development. Geodiverse coastal areas such as GBCs and their coast can provide a source of employment [7], as well as contributing to human well-being, lifelong learning and personal development [19], scientific and educational activities and awareness of geoconservation. It also supports geotourism, which provides social, environmental and economic benefits. According to Cai [24], Çelik Ateş and Ateş [31], Keskin Citiroglu [23], Köroğlu and Kandemir [27], Özgeriş and Karahan [33] and Santos [2], they 
state in their studies that areas with geodiversity encourage economic activity through geotourism. They also emphasize that geotourism is a viable form of local economic development through community participation and has an important role in socio-economic development and sustainable development with the increasing number of visitors.

According to the visitor time table created as a result of the analysis, fewer tourists visited the area during the fall and winter compared to other seasons. Within the context, by increasing geotourism activities, which do not depend on seasons, it is possible to spread tourism to twelve months and provide new employment areas for sustainable local development, create economic growth and increase the welfare of local people.

\subsection{Managerial Implications}

From a managerial point of view, the social, economic [43] and environmental sustainability of the destination is important. In terms of sustainable regional development, the more tourists visit an area, the higher the income will be. Thus, it is of great importance for the management to increase visitor satisfaction in the area. To contribute to the socioeconomic structures of rural areas, it is necessary for the management to evaluate the data regarding visitor understanding.

A Tourism Destination Image (TDI) or a touristic area perception is a traditional area of study in academic literature and is a popular subject in the tourism industry. The comprehensive literature on TDIs is of importance for Destination Management Organizations (DMO) and tourism companies. A TDI is based on understanding the level of brand recognition of the area, developing strategies for the destination and trying to anticipate tourists' behaviors [61].

The international value, management and visibility of geological heritage sites are of particular importance for coastal geotourism. Studies that include on-site surveys measuring visitor views are important as they provide valuable experiential findings in areas such as visitor understanding of geodiversity and visitor satisfaction. Focusing on visitor preferences and/or motivations in the evaluation of geosites significantly influences the success and sustainability of various nature-based tourism types recently represented primarily by coastal geotourism [10].

In this article, important findings were obtained regarding the determination of visitor understanding, expectations and preferences in the evaluation of geoheritage and coastal geotourism potential of GBCs. In parallel with this content of the study, Štrba [10], Crawford and Black [7] and Du Preez [20] emphasize the importance of determining the expectations of visitors and state that the data obtained from visitors are decisive in the sustainability of the original attractiveness and potential of an area in the short and long term.

From the survey findings, it appears that GBCs offer opportunities to improve the visitor learning experience. The majority of the visitors expressed their expectations for a walk with a guide for detailed information in the area. Parallel to this result, as stated in the study of Crawford and Black [7], providing human-guided travel opportunities will be supportive in promoting the area, informing and encouraging visits to similar areas. The provision of more boards, brochures and audio guides should meet the basic needs of visitors and contribute to conservation awareness.

In their five-point Likert evaluations about the GBCs, visitors stated that they highly agreed with the views presented regarding the GBCs' visual appeal, accessibility and unique/rare natural features. The wooden boardwalk along the coast of Güzelcehisar and its connected terraces play an important role in the accessibility, visibility and viewpoint of the GBCs. According to Bentivenga [62], such itineraries greatly contribute to the spread of information on the geological heritage, facilitating the development of geotourism. Not only the existence of areas that are scientifically interesting, but also the beauty of the landscape of the whole region plays a role in the creation of these itineraries. Boardwalk and viewing terraces, which are important for the visibility and accessibility of the GBCs, make it possible to spread information about the geoheritage value of the areas. As 
Hose [63] emphasized, they attract policy-makers' attention and encourage them to plan actions to improve geoconservation and geotourism.

A significant awareness was found among the visitors surveyed in the study, that the GBCs are one of the rare geological formations in the world. As stated by Pralong [64], Reynard [65] and Crawford and Black [7] in previous studies on this subject, uniqueness/rarity has been considered an important criterion in geosite evaluations.

Most of the visitors visit the GBCs on the recommendation of an acquaintance. In order to attract more national and international visitors to the area, the GBCs should be recognized with written and visual materials. It is also important to include the area in the geotourism network. According to the results obtained in this study, the recognition and promotion of the area are important in terms of evaluating the coastal geotourism potential of the GBCs. The significance of this finding was stated by Pralong [64], Pereira [66], Štrba and Rybár [67]; it was also emphasized in the studies of Zouros [68].

Among the visitors' visits to the GBCs, were exploring new places, resting/relaxing and having time away from daily routine. These findings were similar to the studies of Crawford and Black [7] and Štrba [10], as factors affecting geosite visits and geotourism experiences.

According to the survey findings, in the post-visit evaluations, Güzelcehisar's unique coastal cliff characteristics, as well as the coastal landscape diversity, which constituted the strengths of the area in the SWOT analysis specified in Table 1, provided memorable impressions for the visitors. Similarly, Zouros [68], Serrano and González [69] and Vujicic [70] draw attention to the importance of the surrounding landscape and nature while evaluating geosites. In addition to making the study area memorable for visitors, the landscape diversity of Güzelcehisar enables visitors to participate in various touristic and recreational activities, such as walking, taking photographs, enjoying the scenery and swimming, as well as coastal geotourism activities.

As a general evaluation, three main factors emerged that were effective in visiting Güzelcehisar as a coastal geotourism destination. These were the basalt columns, the coastal landscape diversity of Güzelcehisar and the wooden boardwalk. These three main factors positively affected people's choice to visit. As a matter of fact, during the COVID-19 pandemic period, the GBCs and their coast, respectively, were preferred due to the low density of visitors, their seaside location, their boardwalk facility and their suitability for unhindered walking/physical activity along the beach.

Scientific studies that emphasize that geosites contain multidisciplinary geological information $[62,71,72]$, state that South Italy is a significant representative of geological history. The designated geosites enable people to understand the complicated geological history of South Apennine. According to Migoń and Migoń-Pijet [73], geological and geomorphological areas can be considered as a source of beneficial geotourism as they can be used as educational tools to increase risk awareness by preserving the evidence of extreme natural events [74]. Geosites are natural open air laboratories that can be used in environmental education to increase the awareness of natural and geological risks, such as landslides [74]. Similarly, the GBCs provide important information regarding the geological history of the areas.

The sustainable use of seas and coastlines, through an integrated consideration of ecological, economic and social concerns, is increasingly recognized [75,76]. Within the context, it should be integrated into regional development plans within the Integrated Coastal Zone Management within the framework of an understanding that aims to create a geotourism destination in order to ensure the effective protection and sustainable use of the heritage coast value of GBCs and its coast.

\subsection{Limitations and Future Research Directions}

The most obvious limitation of this study was that it was carried out off peak season and focused on only one field. The study provided basic data for future studies. Moreover, the COVID-19 pandemic negatively affected the number of visitors to the area. On the other hand, since it also contains information regarding visitor understanding during the 
pandemic, it can be a guide for future studies on the new normals after the pandemic. The scope of future studies can be expanded by including all the areas in the region that have geotourism potential to obtain more comprehensive findings. For this purpose, the seasons with a high frequency of visits can be studied.

The study only focused on the geotourism potential of an area with a rural coastal landscape character. In the study area, which has different features in terms of landscape diversity, various studies that will be a basis for future tourism development plans can be conducted while considering other rural tourism potentials.

\subsection{Conclusions}

The study tried to answer four main questions in order to determine the visitor understanding of the GBCs in terms of geoheritage and coastal geotourism potential. In this context, most of the visitors had a high level of understanding and awareness of the terms "geodiversity", "geoconservation" and "geoheritage". They had a significant level of awareness about the fact that the GBCs are one of the rare geological formations in the world. In addition, it was emphasized that there was an option for a walk with a guide to improve visitor experience. The landscape diversity in Güzelcehisar also made the study area memorable for visitors. As a result of its landscape diversity, visitors could also participate in recreational activities, such as walking, taking photographs, sightseeing and swimming, in addition to geotourism activities. Moreover, geotourism is an applicable form of local and regional economic development as a result of public contribution. It plays an important role in socioeconomic and sustainable development due to increasing the number of visitors. It was shown that the GBCs and their coast are not only an important employment source, but also have an important potential to support geoconservation and geotourism with activities that focus on well-being, life-long learning, personal development, science and education. The main reasons why visitors preferred the GBCs were discovering new places, relaxation and having time away from their daily routines. Furthermore, increasing the tourism and recreation potential in the coast landscape with rural characteristics contributes to sustainable regional development by diversifying tourism and creating new destinations.

Studies have revealed that the number of visitors in touristic activities in rural areas is effective in sustainable regional development. Sustainable Development Goal 8 encourages sustainable economic growth and employment and, therefore, provides progress and improves residents' life standards [43]. The perception and the satisfaction of visitors influence the number of visitors. The Western Black Sea Region, where there are a lot of areas with rural tourism potential, is important in terms of attaining sustainable developmental goals.

Advertisements of the GBCs and their coast should be intensely encouraged by the local, regional and national administrations. As a result, potential tourists can be informed about the area more, increasing the number of visitors. Furthermore, visitor satisfaction also increases the number of tourists who visit the same area every year. This also increases the number of tourists who recommend the area to other people [43].

This study has scientific importance for the study of rural coastal landscapes, which shows a valuable geodiversity in terms of coastal geomorphology. For the development of coastal geotourism, the Güzelcehisar rural coastal region, which has unique landscape features, was taken as reference. The study presented considerations for promoting the research area to enhance and preserve its geoheritage value through coastal geotourism activities and improving visitor experience through a participatory approach. It also contains scientific data that draw attention to the features of the GBCs and their rural coast and the potential for coastal geotourism.

Coastal zones across the world are often listed as protected areas due to their sensitive ecosystems and frequent social uses. There are geoparks in many coastal zones in the world. A geopark is one of the protected area categories that allows for protection and use [77]. For this reason, the GBCs geopark project, that is supposed to be prepared by the 
local managements, should be planned according to a utilitarian scientific base in terms of geotourism as emphasized by Ertekin [34].

There are few scientific studies on geotourism on the basis of sustainable development in Turkey. Findings from this article will provide a wider interpretation opportunity for areas with similar coastal geotourism potential in Turkey. The GBCs and their coast, with their unique geological and geomorphological features, provide opportunities for coastal geotourism and constitute a special destination that should be evaluated as a heritage coast. In this respect, Güzelcehisar coast and basalt columns are qualified areas in terms of local and regional sustainable development. The study area has the potential to increase the welfare level of the local population by providing a sustainable economic growth and employment opportunities within the context of rural tourism policies based on coastal geotourism.

Author Contributions: Conceptualization, C.C. and B.C.; methodology, C.C., Ş.Ş. and B.C.; formal analysis, C.C. and M.B.B.; statistical computing and software, M.B.B.; investigation, C.C. and B.C.; resources, B.C. and P.K.D.; data curation, M.B.B. and P.K.D.; writing—original draft preparation, C.C., S.SS. and B.C.; writing-review and editing, C.C. and S..Ş.; visualization, M.B.B. and P.K.D. All authors have read and agreed to the published version of the manuscript.

Funding: This research was not funded.

Institutional Review Board Statement: Not applicable.

Informed Consent Statement: Not applicable.

Data Availability Statement: Not applicable.

Conflicts of Interest: The authors declare no conflict of interest.

\section{References}

1. Ólafsdóttir, R.; Tverijonaite, E. Geotourism: A systematic literature review. Geosciences 2018, 8, 234. [CrossRef]

2. Santos, D.S.; Mansur, K.L.; Seoane, J.C.S.; Mucivuna, V.C.; Reynard, E. Methodological proposal for the inventory and assessment of geomorphosites: An integrated approach focused on terriorial management geoconservation. Environ. Manag. 2020, 66, 476-497. [CrossRef] [PubMed]

3. Hose, T. Selling the story of Britain's stone. Environ. Interpret. 1995, 10, 16-17.

4. Newsome, D.; Dowling, R. Setting an agenda for geotourism. In Geotourism: The Tourism of Geology and Landscape; Newsome, D., Dowling, R., Eds.; Goodfellow Publishers Ltd.: Oxford, UK, 2010; pp. 1-12.

5. Burlando, M.; Firpo, M.; Queirolo, C.; Rovere, A.; Vacchi, M. From geoheritage to sustainable development: Strategies and perspectives in the Beigua geopark (Italy). Geoheritage 2011, 3, 63-72. [CrossRef]

6. Erikstad, L. Geoheritage and geodiversity management-the questions for tomorrow. Proc. Geol. Assoc. 2013, 124, 713-719. [CrossRef]

7. Crawford, K.R.; Black, R. Visitor Understanding of the Geodiversity and the Geoconservation Value of the Giant's Causeway World Heritage Site, Northern Ireland. Geoheritage 2012, 4, 115-126. [CrossRef]

8. Brocx, M.; Semeniuk, V. Geoheritage and geoconservation. History, definition, scope and scale. J. R. Soc. West. Aust. 2007, 90, 53-87.

9. Bentivenga, M.; Cavalcante, F.; Mastronuzzi, G.; Palladino, G.; Prosser, G. Geoheritage: The foundation for sustainable geotourism. Geoheritage 2019, 11, 1367-1369. [CrossRef]

10. Štrba, L.; Kršák, B.; Sidor, C. Some comments to geosite assessment, visitors, and geotourism sustainability. Sustainability 2018, 10, 2589. [CrossRef]

11. Brilha, J. Inventory and quantitative assessment of geosites and geodiversity sites: A review. Geoheritage 2016, 8, 119-134. [CrossRef]

12. Esik, Z.; Rozsa, P.; Szepesi, J. Geoheritage elements of millstone manufactory, Tokaj Mountains, Hungary. J. Eur. Fed. Geol. 2019, $48,38-42$.

13. Reynard, E. Geosite. In Encyclopedia of Geomorphology; Goudie, A.S., Ed.; Routledge: London, UK, 2014; Volume 1.

14. Geremia, F.; Bentivenga, M.; Palladino, G. Environmental geology applied to geoconservation in the interaction between geosites and linear infrastructures in south-eastern Italy. Geoheritage 2015, 7, 33-46.

15. Stanley, M. Geodiversity. Earth Herit. 2000, 14, 15-19.

16. Burek, C.V.; Prosser, C.D. The history of geoconservation: An 3introduction. Geol. Soc. Lond. Spec. Publ. 2008, 300, 1-5. [CrossRef]

17. Lazzari, M.; Aloia, A. Geoparks, geoheritage and geotourism: Opportunities and tools in sustainable development of the territory. Geoj. Tour. Geosites 2014, 1, 8-9. 
18. Tavares, A.O.; Henriques, M.H.; Domingos, A.; Bala, A. Community Involvement in Geoconservation: A Conceptual Approach Based on the Geoheritage of South Angola. Sustainability 2015, 7, 4893-4918. [CrossRef]

19. Gordon, E.J. Geoheritage, geotourism and the cultural landscape: Enhancing the visitor experience and promoting geoconservation. Geosciences 2018, 8, 136. [CrossRef]

20. Du Preez, E.A. The contribution of geological features to visitor experiences: Comparison between two geotourism attractions in South Africa. Geoj. Tour. Geosites 2019, 26, 874-888. [CrossRef]

21. Gray, M. Geodiversity: Valuing and Conserving Abiotic Nature; Wiley: Hoboken, NJ, USA, 2004.

22. Pourfaraj, A.; Haderi, E.; Jomehpour, M.; Ferdowsi, S. Conservation management of geotourism attractions in tourism destinations. Geoheritage 2020, 12, 80. [CrossRef]

23. Keskin Citiroglu, H.; Isik, S.; Pulat, O. Utilizing the geological diversity for sustainable regional development, a case studyZonguldak. Geoheritage 2017, 9, 211-223. [CrossRef]

24. Cai, Y.; Wu, F.; Han, J.; Chu, H. Geoheritage and sustainable development in Yimengshan Geopark. Geoheritage 2019, 11, 991-1003. [CrossRef]

25. Dowling, R.K. Geotourism's global growth. Geoheritage 2011, 3, 1-13. [CrossRef]

26. Garofano, M. Geowatching, a term for the popularisation of geological heritage. Geoheritage 2015, 7, 25-32. [CrossRef]

27. Köroğlu, F.; Kandemir, R. Vulnerable geosites of Çayırbağı-Çalköy (Düzköy-Trabzon) in the Eastern Black Sea Region of NE Turkey and their geotourism potential. Geoheritage 2019, 11, 1101-1111. [CrossRef]

28. Suyanto, A.; Haryono, E.; Baiquni, M. Visitors satisfaction Monitoring Using Important Perform Analysis in Pindul GeoheritageIndonesia. IOP Conf. Ser. Earth Environ. Sci. 2020, 451, 012043. [CrossRef]

29. Brilha, J.; Gray, M.; Pereira, D.I.; Pereira, P. Geodiversity: An integrative review as a contribution to the sustainable management of the whole of nature. Environ. Sci. Policy 2018, 86, 19-28. [CrossRef]

30. Yeşil, P.; Yeşil, M.; Yılmaz, H. Jeolojik miras alanlarının alternatif turizm kapsamında değerlendirilmesi: Ballıca Mağarası örneği. Atatürk Üniv. Ziraat Fak. Derg. 2008, 39, 241-248.

31. Çelik Ateş, H.; Ateş, Y. Geotourism and Rural Tourism Synergy for Sustainable Development-Maçka Valley Case-Tunceli, Turkey. Geoheritage 2019, 11, 207-215. [CrossRef]

32. Demir, T.; Aytaç, A.S. Kula UNESCO Global Jeoparkı: Türkiye'nin UNESCO tescilli ilk ve tek global jeopark1. Kula UNESCO Global Geopark: Turkey's first and only global geopark registered by UNESCO. TÜCAUM 30. In Proceedings of the Y1l Uluslararası Coğrafya Sempozyumu International Geography Symposium on the 30th Anniversary of TUCAUM 3-6 Ekim 2018, Ankara, Turkey, 3-6 October 2018.

33. Özgeriş, M.; Karahan, F. Use of geopark resource values for a sustainable tourism: A case study from Turkey (Cittaslow Uzundere). Environ. Dev. Sustain. 2021, 23, 4270-4284. [CrossRef]

34. Ertekin, C.; Ekinci, Y.L.; Büyüksaraç, A.; Ekinci, R. Geoheritage in mythical and volcanic terrain: An inventory and assessment study for geopark and geotourism, Nemrut Volcano (Bitlis, Eastern Turkey). Geoheritage 2021, 13, 73. [CrossRef]

35. Kazancı, N.; Suludere, Y.; Boyraz, S.; Ulaş, D.; Sayılı, S.; Mülazımoğlu, N.S.; Eker, M.; Şahin, Ş.; Yedek, Ö.; Yücel, O.T.; et al. Jeolojik Koruma ve Jeopark Eğitimi; Proje Uygulaması. 64. Türkiye Jeoloji Kurultayı (25-29 Nisan 2011) Bildiri Özetleri Kitabı, Jeoloji Mühendisleri Odası, 2011a. Ankara, Türkiye. s. 321-322. Available online: https://www.jmo.org.tr/resimler/ekler/912a8 8e8d88e44a_ek.pdf (accessed on 20 October 2021).

36. Kazancı, N.; Suludere, Y.; Mülazımoğlu, N.S.; Tuzcu, S.; Turgut, A.; Ulaş, D.; Şahin, Ş.; Yüce, C.; Eker, M. Kızılcahamam (Ankara) Bölgesinde Uygulamalı Jeolojik Miras, Jeopark ve Jeoturizm Eğitimi TÜBİTAK Projesi. 2011b. Proje No: No 110B041, Sonuç Raporu, 21 s., Ankara, Türkiye. Available online: https://dergipark.org.tr/tr/download/article-file/89123 (accessed on 20 October 2021).

37. Kazanc1, N. Geological background and three vulnerable geosites of the Kızılcahamam-Çamlıdere geopark project in Ankara, Turkey. Geoheritage 2012, 4, 249-261. [CrossRef]

38. Cengiz, C.; Cengiz, B.; Bekçi, B.; Tekdamar, D. Bartın Güzelcehisar Kıyı Yerleşiminin Ekolojik Planlaması. Bartın Üniversitesi Bilimsel Araştırma Projesi, 2015. Proje No: BAP-2011-2-26, Bartın, Türkiye. Available online: https://peyzaj.bartin.edu.tr/ arastirma/bap-projeleri.html (accessed on 20 October 2021).

39. Cengiz, C.; Cengiz, B. The Güzelcehisar-Bartın Coastal Landscape Heritage Project. In Proceedings of the International Conference on Sustainable Development, ICSD 2016, Skopje, Macedonia, 19-23 October 2016; pp. 411-419.

40. Cengiz, B.; Cengiz, C.; Karakoç, H. Bartın İli Güzelcehisar Lav Sütunları ve Sahilinin Turizm ve Rekreasyon Amaçlı Peyzaj Uygulama Projesi. 2018. BAKKA 2016 Yılı Küçük Ölçekli Altyapı Mali Destek Programı TR81/16/KÖA/0042 Kodlu Proje Çıktısı, 80 sf., Bartın, Türkiye. Available online: https:/ /www.bakkakutuphane.org/dokuman/bartin-ili-guzelcehisar-lav-sutunlari-vesahilinin-turizm-ve-rekreasyon-amacli-peyzaj-uygulama-projesi/ 409 (accessed on 20 October 2021).

41. Cengiz, B.; Yakan, O.E. Kırsal Peyzajların Sürdürülebilir Gelişimi Bağlamında Kıyısal Alanlarda Görsel Peyzaj Değerlendirmesi: Güzelcehisar Köyü Örneği. Bartın Üniversitesi. Bilimsel Araştırma Projesi, 2019. Proje No: 2018- FEN-CY-009. Bartın, Türkiye. Available online: file:/ / C: /Users/MDPI/AppData/Local/Temp/O\%C4\%9Fuz\%20Erdi\%20pdf.pdf (accessed on 20 October 2021).

42. UNWTO 2021. The World Tourism Organization. Available online: https:/ /www.unwto.org/ (accessed on 20 October 2021).

43. López-Sanz, J.M.; Penelas-Leguía, A.; Gutiérrez Rodríguez, P.; Cuesta-Valiño, P. Sustainable development and consumer behavior in rural tourism - the importance of image and loyalty for host communities. Sustainability 2021, 13, 4763. [CrossRef] 
44. Baixinho, A.; Santos, C.; Couto, G.; de Albergaria, I.S.; da Silva, L.S.; Medeiros, P.D.; Neves, R.M. Creative tourism on islands: A review of the literature. Sustainability 2020, 12, 10313. [CrossRef]

45. Cuesta-Valiño, P.; Bolifa, F.; Núñez-Barriopedr, E. Sustainable, smart and Muslim-friendly tourist destinations. Sustainability 2020, 12, 1778. [CrossRef]

46. Moreno, L.; Ramón, A.; Such, M.J. The challenge of long-term tourism competitiveness in the age of innovation: Spain as a case of study. J. Reg. Res. Investig. Reg. 2018, 42, 13-34.

47. López-Sanz, J.M.; Penelas-Leguía, A.; Gutiérrez-Rodríguez, P.; Cuesta-Valiño, P. Sustainable development and rural tourism in depopulated areas. Land 2021, 10, 985. [CrossRef]

48. Gretzel, U. From smart destinations to smart tourism regions. J. Reg. Res. Investig. Reg. 2018, 42, 171-184.

49. López-Sanz, J.M.; Penelas-Leguía, A.; Gutiérrez-Rodríguez, P.; Cuesta-Valiño, P. Rural tourism and the sustainable development goals. a study of the variables that most influence the behavior of the tourist. Front. Psychol. 2021, 12, 722973. [CrossRef]

50. Puška, A.; Pamucar, D.; Stojanovi'c, I.; Cavallaro, F.; Kaklauskas, A.; Mardani, A. Examination of the sustainable rural tourism potential of the Brcko district of Bosnia and Herzegovina using a fuzzy approach based on group decision making. Sustainability 2021, 13, 583. [CrossRef]

51. Hence, B.G.; Salvaj, E.; Cuesta-Valino, P. A Sustainable management model for cultural creative tourism ecosystems. Sustainability 2020, 12,9554 .

52. Cristobal-Fransi, E.; Daries, N.; Ferrer-Rosell, B.; Marine-Roig, E.; Martin-Fuentes, E. Sustainable tourism marketing. Sustainability 2020, 12, 1865. [CrossRef]

53. Anonymous. Güzelcehisar Village Culture and Tourism Inventory; Bartın Provincial Directorate of Culture and Tourism Archive: Bartın, Turkey, 2012.

54. Anonymous. Bartın Güzelcehisar First Degree Archaeological Site Conservation Plan 1/5000 Scale Master and 1/1000 Scale Implementation Development Plan Research and Plan Description Report; Bartın Special Provincial Administration: Bartın, Turkey, 2011.

55. Tokay, M. Geologie De La Region De Bartın. Bull. Miner. Res. Explor. 1955, 46.

56. Chauhan, G.; Baiswas, S.K.; Thakkar, M.G.; Page, K.N. The Unique geoheritage of the Kachchh (Kutch) Basin, Western India, and its conservation. Geoheritage 2021, 13, 23. [CrossRef]

57. Taber, K.S. The Use of Cronbach's Alpha When Developing and Reporting Research Instruments in Science Education. Res. Sci. Educ. 2018, 48, 1273-1296. [CrossRef]

58. Ramos, D.M.B.; Cost, C.M.M. Coastal tourism in rural areas: Development model. Int. J. Entrep. Innov. Manag. 2017, 21. [CrossRef]

59. Povilanskas, R.; Baziuke, D.; Ducinskas, K.; Urbis, A. Can visitors visually distinguish successive coastal landscapes? A case study from the Curonian Spit (Lithuania). Ocean Coast. Manag. 2016, 119, 109-118. [CrossRef]

60. Ergin, A.; Özölçeri, H.; Şahin, F. Evaluating coastal scenery using fuzzy logic: Application at selected sites in western Black Sea coastal region of Turkey. Ocean Eng. 2010, 37, 583-591. [CrossRef]

61. Cuesta-Valiño, P.; Serra-Cantallops, A.; Ramón-Cardona, J.; Ravina-Ripoll, R. China viewed by the west before COVID-19: Spaniards' perceptions and knowledge of China as a tourist destination. Land 2021, 10, 950. [CrossRef]

62. Bentivenga, M.; Palladino, G.; Prosser, G.; Guglielmi, P.; Geremia, F.; Laviano, A. A geological itinerary through the southern Apennine Thrust Belt (Basilicata-Southern Italy). Geoheritage 2017, 9, 1-17. [CrossRef]

63. Hose, T.A. European geoturism-geological interpretation and geoconservation promotion for tourists. In Geologica Heritage: Its Conservation and Managenment; Barretino, D., Wimbledon, W.P., Gallego, E., Eds.; Instituto Tecnologico Geominero de Espana: Madrid, Spain, 2000; pp. 127-146.

64. Pralong, J.P. A method for assessing the tourist potential and use of geomorphological sites. Géomorphol. Relief Process. Environ. 2005, 3, 189-196. [CrossRef]

65. Reynard, E.; Fontana, G.; Kozlik, L.; Scapozza, C. A method for assessing "scientific" and "additional values" of geomorphosites. Geogr. Helv. 2007, 62, 148-158. [CrossRef]

66. Pereira, P.; Pereira, D.I.; Alves, M.I.C. Geomorphosite assessment in Montesinho Natural Park (Portugal). Geogr. Helv. 2007, 62, 159-168. [CrossRef]

67. Štrba, L.; Rybár, P. Revision of "Assessment of attractiveness (value) of geotouristic objects". Acta Geoturistica 2015, 1, 30-40.

68. Zouros, N. Geomorphosite assessment and management in protected areas of Greece. The case of the Lesvos Island-Coastal geomorphosites. Geogr. Helv. 2007, 62, 169-180. [CrossRef]

69. Serrano, E.; González, J. Assessment of geomorphosites in natural protected areas: The Picos de Europa National Park (Spain). Geomorphol. Relief Process. Environ. 2005, 3, 197-208. [CrossRef]

70. Vujicic, M.D.; Vasiljevic, D.A.; Markovic, S.B.; Hose, T.A.; Lukic, T.; Hadžic, O.; Janicevic, S. Preliminary geosite assessment model (GAM) and its application on Fruška Gora Mountain, potential geotourism destination of Serbia. Acta Geogr. Slov. 2011, 51, 361-377. [CrossRef]

71. Palladino, G.; Prosser, G.; Bentivenga, M. The geological itinerary of Sasso di Castalda: A journey into the geological history of the Southern Apennine thrust-belt (Basilicata-Southern Italy). Geoheritage 2013. [CrossRef]

72. Bucci, F.; Tavarnelli, E.; Novellino, R.; Palladino, G.; Guglielmi, P.; Laurita, S.; Prosser, G.; Bentivenga, M. The History of the Southern Apennines of Italy preserved in the geosites along a geological itinerary in the high Agri Valley. Geoheritage 2019, 11, 1489-1508. [CrossRef]

73. Migoń, P.; Migoń-Pijet, E. Natural disasters, Geotourism, and geointerpretation. Geoheritage 2018. [CrossRef] 
74. Gizzi, F.T.; Bentivenga, M.; Lasaponara, P.; Danese, M.; Potenza, M.R.; Sileo, M.; Masini, N. Natural hazards, human factors, and "Ghost Towns": A multi-level approach. Geoheritage 2019, 11, 1533-1565. [CrossRef]

75. Douvere, F.; Ehler, C.N. New perspectives on sea use management: Initial findings from European experience with marine spatial planning. J. Environ. Manag. 2008, 90,77-88. [CrossRef] [PubMed]

76. Kobryn, H.T.; Brown, G.; Munro, J.; Moore, S.A. Cultural ecosystem values of the Kimberley coastline: An empirical analysis with implications for coastal and marine policy. Ocean Coast. Manag. 2018, 162, 71-84. [CrossRef]

77. Moreira, J.C.; Vale, T.F.d.; Burns, R.C. Fernando de Noronha Archipelago (Brazil): A coastal geopark proposal to foster the local economy, tourism and sustainability. Water 2021, 13, 1586. [CrossRef] 